\title{
Orta Ölçekli Bir Şehirde Kentsel Su Yönetimi: Amasya İli Merzifon İlçesi Örneği
}

\section{Urban Water Management in a Medium-Scale City: The Case of Merzifon District of Amasya Province}

\author{
Mustafa Tuna $^{1}$, Selim Armut ${ }^{2^{*}}$ \\ Geliş / Received: 26/08/2021 \\ Revize / Revised: 30/11/2021 \\ Kabul / Accepted: 04/12/2021
}

ÖZ

Bu çalışmada orta ölçekli bir şehirde kentsel su yönetiminin incelenerek suyun kaynaktan alınıp içme suyu iletim ve dağıtım hatlarıyla hizmete sunulması, atık suyun arıtılarak ekolojik ortama deşarj edilmesindeki süreçlerde oluşan sorunlar ele alınmıştır. Bu kapsamda Merzifon ilçesindeki kentsel su yönetimi su kaynakları, içme suyu iletim dağıtım şebekesi, su abone verileri, atık su sistemi, yağmursuyu sistemi incelenerek değerlendirilmiştir. İlçede içme suyu kaynaklarının oldukça kısıtlı olduğu, ancak içme suyu kapasitesinin artırılması ve şehir içi şebekesinin yenilenmesi ile ilgili olarak yapılan çalışmalarda sonuca ulaşılmasında zorluklar olduğu, buna karşılık su talebinin her geçen gün arttığı tespit edilmiş̧ir. Kısa vadede gerekli önlemlerin alınmaması halinde ilçeyi büyük içme suyu sorununun beklediği ve bunun da sadece yerel yönetimin alacağı önlemlerle çözülemeyeceği dikkati çekmektedir. Orta ve büyük ölçekli şehirlerde su yönetimi sorunlarının çözümü için proje geliştirme, uygulama, şebeke yenileme, fiyatlama ve diğer işletme faaliyetlerinin yeniden gözden geçirilmesi ve iklim değişikliği riskleri de dikkate alınarak kentsel su yönetiminin yeniden düzenlenmesine gereksinim olduğu açıktır. Kentsel su arzı ve talebini teknik, mali, ekonomik, çevresel yönleri ile analiz edebilecek, havza ve alt havzalar düzeylerinde su yönetimi modellerinin geliştirilmesi, uygulanmasına olanak verebilecek tüzel kişiliğe haiz idari yapının oluşturulması gerekmektedir. Çok amaçlı kullanılan su kaynakları yönetiminin daha profesyonel bir yaklaşımla ele alınması zorunlu görülmektedir.

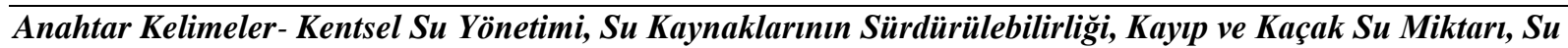
Ekonomisi ve Geleceği

\footnotetext{
ABSTRACT

In this study, water management in a medium-sized city is examined, and the problems that occur in the processes of taking water from the source and putting it into service through drinking water transmission and distribution lines, discharging wastewater to the ecological environment are discussed. In this context, urban water management in Merzifon district has been evaluated by examining water resources, drinking water transmission and distribution network, water subscriber data, wastewater system and storm water system. It has been determined that the drinking water resources in the district are quite limited, but there are difficulties in reaching the result in the studies on both increasing the drinking water capacity and renewing the drinking water network, while the demand for water is increasing day by day. It has been observed that if the necessary measures are not taken in the short-term period, a major drinking problem awaits the district, and this cannot be solved by the measures taken by the local government alone. It is clear that project development, implementation, network renewal, pricing and 1İletişim: mtuna57@gmail.com (https://orcid.org/0000- 0002- 9614- 6076) Gayrimenkul Geliştirme ve Yönetimi Bölümü, Uygulamalı Bilimler Fakültesi, Ankara Üniversitesi, Ankara, Türkiye 2*Sorumlu yazar iletişim: selimarmut05@gmail.com (https://orcid.org/0000-0001-6506-8960) Gayrimenkul Geliştirme ve Yönetimi Anabilim Dall, Fen Bilimleri Enstitüsü, Ankara Üniversitesi, Ankara, Türkiye
} 
other operational activities need to be reviewed in order to solve water management problems in medium and large-scale cities, and urban water management needs to be reorganized by taking into account the risks of climate change. It is necessary to establish an administrative structure with legal personality that can analyze the urban water supply and demand in terms of technical, financial, economic and environmental aspects, and that can enable the development and implementation of water management models at the basin and sub-basin levels. A more professional approach to the management of multi-purpose water resources is required.

\section{Keywords- Urban Water Management, Sustainability of Water Resources, Amount of Lost and Leaked Water,} Water Economics and It's Future

\section{I.GİRiş}

İnsan hayatının sürdürülmesi için gerekli olan en önemli doğal kaynaklardan biri de sudur. Su kaynaklarından çok yönlü yararlanılmaktadır. Özellikle hızlı kentleşme, nüfus artışı, küresel ısınma kaynaklı yağış azlığı, aşırı buharlaşma, evsel, tarımsal, endüstriyel atıkların neden olduğu kirlenme, aşırı tüketim gibi sorunlar nedeniyle mevcut kaynaklardan doğrudan yararlanma olanakları azalmaktadır. Dolayısıyla yeterli nitelikte su tedarikinin maliyeti yükselmektedir [1,2]. Son yıllarda ülkelerin, su ihtiyacını karşılarken su kaynaklarının çevre ile uyumlu olarak kullanılması ve geliştirilmesini sağlayan yönetimlere yöneldikleri görülmektedir [2,3]. Su yönetimi alanındaki sorunlardan bir diğeri de mevcut kaynakların kim tarafından nasıl yönetilmesi gerekliğine karar verilmesidir. Birçok ülkede kentsel mekan hızla büyümekte, kentleşme düzeyi ve nüfus artış hızına bağlı olarak suya olan talep her geçen gün artı̧̧ göstermektedir [4-6]. Kent ölçeğinde gerekli olan içme suyunun kaynağa zarar vermeden alınarak belli standartlarda temin edilmesi, kullanımının ardından çevresel hasara neden olmadan arıtımının yapılarak doğal ortama deşarj edilmesi gerekmektedir.

Küresel ısınma ile meydana gelen iklim değişiklikleri sonucu yağış rejimlerinde meydana gelen değişimler kuraklık ve sel baskınlarının artmasına neden olmaktadır. Kuraklık ile birlikte suya olan talep artmakta su kaynakları baskı görmektedir. Şiddetli yağışların artmasına paralel olarak su baskınları da artmaktadır. Bu olumsuz durumlardan kaynaklanan kentsel su hizmetlerinin yürütülmesinde zorluklar ortaya çıkmaktadır. Kısıtlı kaynakların verimli şekilde kullanımı zorunluğu ortaya çıkmakta, kent su ve kanalizasyon şebekelerinin bakım onarımlarının düzenli olarak yapılması gerekmektedir. İçme suyu şebekelerinin kayıp kaçak miktarlarının takip edilerek minimum düzeylerde tutulması, kanalizasyon ve yağmursuyu şebekelerinin düzenli olarak temizliklerinin yapılarak hizmet vermelerinin sağlanması gerekmektedir. Su, kanalizasyon ve yağmursuyu șebekeleri ile arıtma tesisleri sürekli olarak çalışan varlıklar olduğundan, bunların sürekli olarak izlenerek aksaklıklarının giderilmesi zorunlu olmaktadır.

Kentsel su yönetiminin sürdürülebilir şekilde gerçekleştirilmesi için içme suyu, kanalizasyon, arıtma tesisi, yağmursuyu projelerinin hayata geçirilmesi, bunlara ilişkin sermaye, işletme ve finansal maliyetlerinin karşılanması gerekmektedir $[1,3,6]$. Ayrıca genişleme, bakım onarım, yenileme programları için fonlama planının oluşturulması zorunluluktur. Suyun farklı kullanımlar için tahsisi ve ücretinin (veya fiyatının) tespiti; hem kıt kaynağın etkin kullanımı, hem de gelecek nesillere yeterli ve kullanılabilir kaynak bırakılması yönlerinden özel önem taşımaktadır. Bu çalışmanın amacı orta ölçekli bir şehir olan Merzifon’un kentsel su yönetiminin; ilgili belediye ve kamu kurumlarının kayıtlarına dayalı olarak incelenmesi, geleceğe yönelik değerlendirme yapılmasıdır. İlçenin su kaynakları, su iletim dağııı şebekelerinin durumu, kanalizasyon şebekesi, yağmursuyu şebekesi, atık su arıtımı sistemi, su abonelik verileri ve ilçede kentsel su yönetiminde karşılaşılan sorunlar ele alınmıştır.

\section{KENTSEL SU YÖNETIMINDE PAYDAŞLAR}

Türkiye'de su yönetimi merkezi olarak gelişmiştir. Anayasa'nın 168. maddesine göre, tabii servetler ve kaynaklar devletin hüküm ve tasarrufu altındadır. Devlet bunların aranması ve işletilmesi hakkını gerçek ve tüzel kişilere devredebilir. Su evsel, sanayi, sulama, enerji gibi çok amaçlı kullanım alanlarına sahip olduğundan bir çok kurum ve kuruluşun çalışma alanına girmektedir. Bu kurumlardan bir kısmı merkezi idarenin tasarrufu altındaki kamu kurumları, bir kısmı ise kısmen merkezi idare tasarrufu olan yerel idarelerdir. Kurumlar kanunlarla belirlenen yetkilerine göre su kaynakları yönetimine ilişkin faaliyetlerini gerçekleştirmektedir.

Şehir ve kasabaların içme suyu ve kanalizasyon projelerinin incelenmesi, onaylanması ve denetlenmesi DSİ Genel Müdürlüğünün Teşkilat ve Görevleri Hakkındaki Kanun'da (TC Resmi Gazete, Tarih:25.12.1953, Sayı:6200) DSİ'nin görevleri arasında sayılmıştır. Yer altı suları ile ilgili düzenlemelerin yer aldığı 167 sayılı 
Kanun'da (TC Resmi Gazete, Tarih: 23.12.1960, Sayı: 167) yer altı suları ile ilgili arama izni, kullanma izni, tahsisi ile ilgili DSİ yetkilendirilmiş̧ir. Yeraltı suyu işletme sahalarının sınırları DSİ tarafından tespit edilmektedir. Bu sahalar içerisindeki belge alarak açılacak kuyuların adedi, yeri, derinliği, çekilecek su miktarları DSİ tarafından belirlenmektedir. Su kaynaklarının tahsisi, ruhsatlandırılması, kiralanması gibi işlemlerde DSİ'nin görüşünün alınması gerekmektedir. Su Tahsisleri Hakkındaki Yönetmeliğe (TC Resmi Gazete, Tarih: 10.12.2019, Sayı: 30974) göre su kullanımındaki öncelik sırasını içme- kullanma suyu ihtiyacı, çevresel su ihtiyacı, tarımsal sulama, su ürünleri yetiştiriciliği, enerji üretimi, sınai su ihtiyaçları, ticari, turizm, rekreasyon, madencilik, taşıma, ulaşım ile sair su ihtiyaçları oluşturmaktadır.

İller Bankası finansal ve teknik anlamda yerel yönetimlerin gelişmesine katkı sağlamaktadır. İl Özel İdareleri ve Belediyelerin finansman ihtiyacının karşılanması, mahalli müşterek hizmetlere ilişkin projeler geliştirilmesi, danışmanlık, denetim hizmeti verilmesi İller Bankası tarafından gerçekleştirilmektedir. Merkezi hükümetin mahalli idarelere her türlü kaynak transferine aracılık edilmesi, her türlü yatırım ve kalkınma bankacılığı işlevlerinin yerine getirilmesi amaçları arasındadır. İller Bankası istemeleri halinde yerel yönetimlere içme suyu, kanalizasyon, arıtma tesisi yapılmasında kredi sağlamaktadır. Bu işler için plan, proje, harita, etüt, inşaat işlerini yapmakta veya yaptırmaktadır [7].

2011 yılında su yönetiminde koordinasyonun sağlanması amacıyla kurulan Su Yönetimi Genel Müdürlüğünün hedefleri arasında havza bazında su kaynaklarının korunması, iyileştirilmesi, kullanılmasına dönük politikalar belirlemek yer almaktadır. Kamu kurum kuruluşları su ile ilgili verileri talep edilmesi halinde $\mathrm{Su}$ Yönetimi Genel Müdürlüğüne vermekle yükümlüdür. İçme ve kullanma suyu arıtma tesislerinin tasarım esasları, normları ve kriterlerini belirler. Projeyi onaylamaya yetkili kurumların tespitini, tesisi işletecek elemanların eğitimlerinin temin edilmesini sağlamaktadır.

Avrupa Birliği ve Dış İlişkiler Genel Müdürlüğü Avrupa Birliği’ne yönelik mevzuat ve uyum çalışmaları ile ekonomik, teknik işbirliğine yönelik çalışmalarda irtibatı sağlamaktadır. Mali ilişkiler çerçevesinde operasyonel programların yürütülmesini ve fonların uygulanmasını takip etmektedir. Desteklenecek projelerle ilgili proje seçiminin yapılması, önceliklendirilmesi, ihale ve sözleşmelerin yapılmasının sağlanması, ödemelerin gerçekleştirilmesi, muhasebeleştirilmesi, kontrol, izleme, değerlendirmelerin yapılması Avrupa Birliği ve Dış İlişkiler Genel Müdürlüğ̈̈nün görevlerindendir.

Çevre Yönetimi Genel Müdürlüğü çevre kirliliğinin önlenmesi amacıyla standartlar oluşturmaktadır. Alıcı ortam özelliklerine göre çevre kirliliği yönünde görüş verilmesi, yeraltı ve yerüstü sularının korunması amacıyla kirletici unsurlar ile kirliliğin giderilmesi, kontrolüne ilişkin usul ve esasları tespiti ve uygulamasının sağlanmasını amaçlamaktadır. Atık su arıtma tesislerinin tasarım esaslarını Tarım ve Orman Bakanlığı ile birlikte belirlenmekte, onay işlemlerinin yürütülmesini sağlamaktadır.

Sağlık Bakanlığı, İl ve İlçe Sağlık Müdürlükleri vasıtasıyla kentlerde tüketim için şebekeye verilen içme ve kullanma suyunun kalitesini izlemektedir. Bu amaçla numune alınması, gerekli analizlerin yaptırılması, içme suyu şebekesinin bakiye klor ölçümlerinin sürekli olarak yapılması hizmetlerini vermektedir.

Milli Emlak Genel Müdürlüğü devletin hüküm ve tasarrufu altındaki yerlerin kamu hizmetlerinde kullanılması için gerekli olanları kamu idarelerine tahsis edebilmektedir. Kentsel su yönetiminde ihtiyaç duyulan depo, kaynak, tesis yapmak amacıyla tahsis işlemlerinin gerçekleştirilmesinde rol oynayabilmektedir.

Yerel düzeyde kentsel su tedarik ve idaresi, 831 sayll Sular Hakkında Kanun'da (TC Resmi Gazete, Tarih:28.04.1926, Sayı: 368), belediyelere verilmiştir. Belediyelerin mahalli müşterek nitelikli olmak kaydıyla su ve kanalizasyon hizmetlerini yapacağı ve yaptıracağ 5393 sayılı Belediye Kanununun 14. maddesinde hüküm altına alınmış̧ır. Belediyelerin kentsel su yönetimi ile ilgili yetki ve sorumlulukları aynı Kanun'da belirtilmiştir. Belediyeler su ve atık su alacaklarını tahsilini yapmak ve yaptırmakla görevlidir. İçme, kullanma ve endüstri suyu sağlanması, atık su ve yağmur suyunun uzaklaştırılmasının sağlanması, bunlar için gerekli tesislerin kurulması, kurdurulması, işletilmesi ve işlettirilmesi belediyelerin görev ve yetkilerinden sayılmıştı. Belediyeler belediye meclisi kararı ile baraj, arıtma tesislerine ait hizmetler, kanal bakım ve temizleme, sayaç okuma, sayaç sökme takma işleri ile ilgili hizmetler süresi ilk mahalli idareler seçimlerini izleyen altıncı ayın sonunu geçmemek üzere ihale edebilmektedir. Belediyeler, kanunların verdiği yetki çerçevesinde yönetmelik çıkarabilmekte, belediye yasakları koyabilmekte ve uygulayabilmekte, yönetmeliklerinde belirtilen cezaları verebilmektedir.

1986 yılında 3305 sayılı Kanun ile 2560 sayılı İstanbul Su ve Kanalizasyon İdaresi Genel Müdürlüğü Kuruluş ve Görevleri Hakkındaki Kanun yeniden düzenlenmiştir. Böylece 2560 sayılı Kanun tüm büyükşehir belediyelerinde uygulanmıştır. Su ve kanalizasayon idareleri kurulmuştur. Büyükşehir belediyeleri içme, 


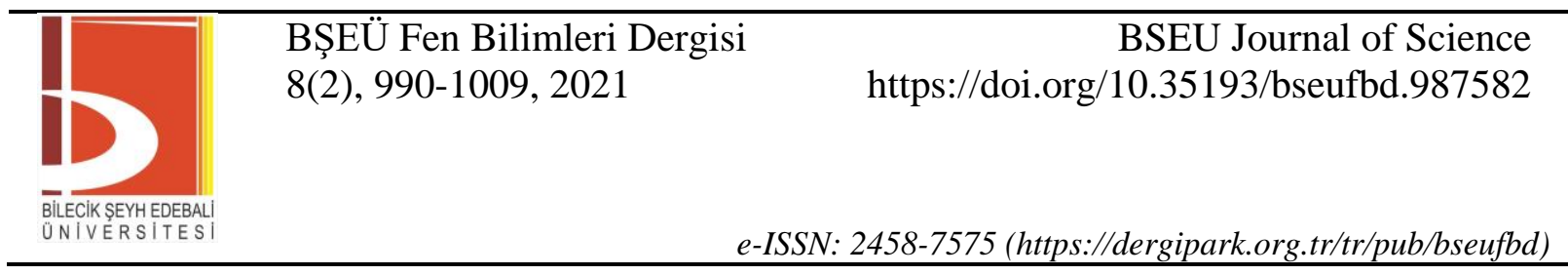

kullanma, endüstri suyu ihtiyaçlarının karşılanmasından sorumlu olmuştur. Atık su, yağmursuyu ve içme suyu hizmetlerinin verilmesinde görev, yetki ve sorumluluklara sahiptir.

\section{MERZIFON ILÇESINDE KENTSEL SU YÖNETIMI}

Merzifon ilçesinde kentsel su yönetiminin incelenmesi içme suyu kaynakları, içme suyu şebekesi, kanalizasyon sistemi, atık su arıtımı, yağmursuyu sistemi, su abonelik verileri ve kentsel su yönetimi sorunları kapsamında gerçekleştirilmiştir. Mevcut içme suyu kaynaklarının ve içme suyu temin sisteminin su talebindeki değişiklikleri karşılama durumu abonelik verileri de dikkate alınarak değerlendirilmiştir. Kanalizasyon sisteminin ve atık su arıtımının sağlıklı bir şekilde işletilebilmesindeki sorunlar irdelenmiştir.

\section{A. İlçenin Genel Tanıtımı}

Merzifon ilçesi, Amasya'ya bağlı olup, Karadeniz Bölgesi’nin Orta Karadeniz bölümünde yer almaktadır. Amasya'ya 47 km, Çorum'a 67 km, Samsun'a 115 km, Ankara'ya 310 km ve İstanbul'a 625 km uzaklıktadır. Güneyinde Çorum ili, kuzeyinde Samsun ili, batısında Gümüşhacıköy, Hamamözü ilçeleri ve doğusunda Suluova ilçesi yer almaktadır. İlçe, Karadeniz Bölgesini batıya, İç Anadolu Bölgesini doğuya bağlayan kavşak durumundadır. Merzifon ilçesinin 1970-2020 döneminde nüfus, nüfus artışı, göç ve hane büyüklüğü gibi demografik verileri Tablo 1'de sunulmuştur. İlçe nüfusu 74 bine yaklaşmakta ve ortalama hane büyüklügü ülke genelinde olduğu gibi 3 kişi düzeyine kadar gerilemiş̧ir.

Tablo 1. Merzifon ilçesi nüfusu ve yoğunluk [6,7]

\begin{tabular}{ccccc}
\hline Yıllar & Nüfus (Kişi) & $\begin{array}{c}\text { Nüfus Artışı } \\
(\% \mathbf{0})\end{array}$ & $\begin{array}{c}\text { Fiziksel Nüfus } \\
\text { Yoğunluğu (Kişi/Km } \mathbf{K}^{\mathbf{2}}\end{array}$ & $\begin{array}{c}\text { Ortalama Hanehalkı } \\
\text { Büyüklüğü (İl Düzeyi) }\end{array}$ \\
\hline 1970 & 59.389 & & 61,1 & - \\
1976 & 60.672 & 2,16 & 62,4 & - \\
1980 & 62.133 & 2,41 & 63,9 & - \\
1986 & 68.260 & 9,86 & 70,2 & - \\
1990 & 67.448 & $-1,19$ & 69,4 & - \\
2000 & 67.281 & $-0,25$ & 69,2 & 3,7 \\
2007 & 69.093 & 2,69 & 71,1 & 3,6 \\
2010 & 69.237 & 0,21 & 71,2 & 3,2 \\
2015 & 70.132 & 1,29 & 72,2 & 3,1 \\
2016 & 70.132 & 0,00 & 72,2 & 3,1 \\
2017 & 71.853 & 2,45 & 73,9 & 3,1 \\
2018 & 71.916 & 0,09 & 74,0 & 3,0 \\
2019 & 72.277 & 0,50 & 74,4 & \\
2020 & 73.849 & 2,17 & 76,0 & \\
\hline
\end{tabular}

İller Bankası Genel Müdürlüğ̈̈ tarafından yapılan projelerde kullanılan formül ve kabullerle ilçenin 2050 projeksiyonu yapılmıştır. Gelecekteki nüfus ve içme suyu ihtiyacı Tablo 2'de sunulmuştur. İlçenin 2025 yılı nüfusunun 78 bin kişi ve toplam su ihtiyacının 170 1/s ve 2050 yılında ise toplam su ihtiyacının 200 1/s dolayında olacağı görülmektedir. Buna göre artan nüfusla birlikte su talabinin artacağı açıkça görülmektedir.

Tablo 2. İlçenin gelecekteki nüfusu ve içme suyu ihtiyacı [6,22]

\begin{tabular}{ccc}
\hline Yıllar & Nüfus (Kişi) & Toplam Su İhtiyacı (l/s) \\
\hline 2025 & 77.469 & 170 \\
2030 & 81.421 & 175 \\
2035 & 85.574 & 180 \\
2040 & 89.940 & 185 \\
2045 & 94.527 & 195 \\
2050 & 99.349 & 200 \\
\hline
\end{tabular}

Merzifon ilçesinde eski yerleşim alanı sit alanı ve çevresinde kurulmuştur. Kentteki gelişmelere paralel olarak 2000 yılında yapılan imar planı 60.000 kişilik nüfus için 1294 ha alanda, 2012 yılında yapılan imar planı ise 70.000 nüfus için 1400 ha alanda onaylanmıştır. İlçede sanayi faaliyetleri gelişmektedir. Organize Sanayi bölgesi altyapı çalışmaları 1995 yılında başlamış, 2002 yılında tamamlanmıştır. 2012 yılından itibaren 43 ha alana ilave kısımla birlikte toplamda 155 ha alanda sanayi amaçlı alan oluşturulmuştur. 2008 yılı içerisinde Merzifon havaalanı sivil taşımacılığa açılmıştır. 2014 yılında Merzifon İktisadi ve İdari Bilimler Fakültesi kurulmuştur. Bu özellikler ilçe nüfusunun artma eğiliminde olduğunu göstermektedir. 


\section{B. İçe Suyu Kaynakları ve Su Şebekesi Durumunun İncelenmesi}

Bu kısımda ilçenin içme suyu temin ettiği kaynaklarının ve içme suyu şebekesinin durumu incelenmiştir. İçme suyu kaynaklarının debilerinde zamanla meydana gelen değişimlerle içme suyu şebekesinin verimliliği değerlendirilmiştir.

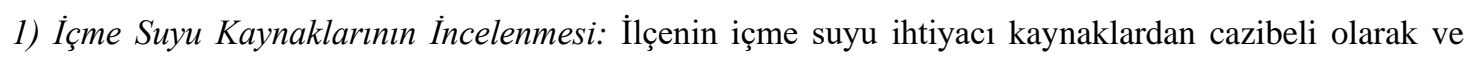
yeraltı su kuyularından pompajla temin edilmektedir. Merzifon ilçesinin içme suyu ihtiyacının karşılanması amacıyla 1951 yılında Tavşan dağının eteklerinden doğan Muşruf deresi civarındaki 21 adet göze toplanarak içme suyu deposuna isale edilmiştir. 1985 yllında yenilenen isale hattıyla aynı dere üzerinde yeni kaynaklar ilave edilerek 50 1/s su temin edilmiştir. Kayalık kaynakları ise mülga İmar ve İskân Bakanlığı tarafından 1979 yılında onaylanan projenin hukuki problemlerinin 1991 yılında çözülmesiyle belediye tarafından projesine göre inşaatı tamamlanarak mevcut su deposuna 24 1/s su iletilmiştir. Muşruf ve Kayalık kaynaklarından derlenen sular cazibeli olarak içme suyu temin edilen su kaynaklarını oluşturmaktadır. Muşruf ve Şırgayıp (Kayalık) kaynaklarına ait debi değişimleri Tablo 3'de sunulmaktadır.

Tablo 3. Kaynak sularının debi (1/s) değişimleri [18]

\begin{tabular}{ccc}
\hline Yıllar & $\begin{array}{c}\text { Muşruf } \\
\text { Kaynağı }\end{array}$ & $\begin{array}{c}\text { Şırgayıp } \\
\text { Kaynağı }\end{array}$ \\
\hline $\mathbf{2 0 1 7}$ & 13 & 15 \\
$\mathbf{2 0 1 8}$ & 7 & 9 \\
$\mathbf{2 0 1 9}$ & 8 & 11,5 \\
$\mathbf{2 0 2 0}$ & 2,5 & 8 \\
\hline
\end{tabular}

Kaynak suları debileri ilkbaharda artmakta sonbaharda azalmaktadır. Her iki kaynak içinde debinin en düşük olduğu kasım ayına bakıldığında Muşruf kaynağında 4 yıl içerisinde 13 1/s'den 2,50 1/s'ye düşerek yaklaşık \% 81, Şırgayıp (Kayalık) kaynağı 15 1/s'den 8 1/s'ye düşerek yaklaşık olarak \% 47 azaldığı görülmektedir.

Merzifon ilçesinin yerleşim alanı, Muşruf ve Paşa Deresinin oluşturduğu koni olarak adlandırılan alüvyal dolgu malzemesi üzerinde yer almaktadır. 1953 yılında açılan kuyunun arızalanması ardından 3 adet derin kuyu açılarak toplanda 80 1/s su temin edilmiştir. İller Bankası tarafından 1985 yılında Paşa deresine açılan 3 adet kuyu yenilenmiştir. Daha sonraki yıllarda ilçenin içme suyu temini amacıyla Paşa Deresi ve Kuruçay Deresi üzerinde belediye tarafindan kuyular açılmıştır. Mevcut durumda içme suyu bu derelerden beslenen 15 adet derin kuyudan sağlanmaktadır. Yeraltı suyu verimlerinin değerlendirilmesi kuyu ruhsatlarındaki debilerle güncel su debilerinin karşılaştırılması, kullanılan kuyuların seviye değişimlerinin karşılaşıtırılması ardından ilçeye yağışlarla sağlanan beslenim miktarının su kullanım miktarlarıyla karşılaştırılması yoluyla değerlendirilmiştir. Belediyenin içme ve kullanma suyu temin ettiği kuyulara ait debi (l/s), derinlik (m), dinamik seviye (m) değerleri Tablo 4'de sunulmaktadır. 


\begin{tabular}{|c|c|c|}
\hline & $\begin{array}{l}\text { BŞEÜ Fen Bilimleri Dergisi } \\
8(2), 990-1009,2021\end{array}$ & $\begin{array}{r}\text { BSEU Journal of Science } \\
\text { https://doi.org/10.35193/bseufbd } 987582\end{array}$ \\
\hline & & 2458-7575 (https://dergipark.org.tr/tr/pub/bseufbd) \\
\hline
\end{tabular}

Tablo 4. İçme suyu temininde kullanılan kuyuların verileri [14,18,22]

\begin{tabular}{lcccc}
\hline \multicolumn{1}{c}{ Kuyu adı } & $\begin{array}{c}\text { Kuyu } \\
\text { Ruhsat } \\
\text { Verimi } \\
(\mathbf{l} / \mathbf{s n})\end{array}$ & $\begin{array}{c}\text { Kuyu } \\
\text { Güncel } \\
\text { Verimi } \\
(\mathbf{l} / \mathbf{s n})\end{array}$ & $\begin{array}{c}\text { Kuyu } \\
\text { derinliği } \\
(\mathbf{m})\end{array}$ & $\begin{array}{c}\text { Tahsisle } \\
\text { çekilebilecek su } \\
\text { miktarı } \\
\left(\mathbf{m}^{3} / \mathbf{y ı l}\right)\end{array}$ \\
\hline Hıra & 35 & 9,3 & 140 & 567.575 \\
25 Lüle & 20 & 18,4 & 130 & 757.010 \\
İtfaiye & 25 & 17,1 & 160 & 949.000 \\
Kefeli & 55 & 12,5 & 141 & 346.750 \\
Hastane-1 & 40 & 21 & 118 & 757.010 \\
Hastane-2 & 35 & 21,7 & 152 & 757.010 \\
Hastane-3 & 19 & 18,3 & 120 & 757.010 \\
M. Akif & 39 & 18,3 & 160 & 788.400 \\
Karatepe & 22 & 21 & 150 & 365.000 \\
K. Mustafa Paşa & 19 & 19 & 150 & 933.120 \\
Yörükler & 20 & 10,7 & 140 & 409.895 \\
Piribaba & 35 & 8,5 & 125 & 788.400 \\
Motorhane & 35 & 19,4 & 142 & 313.900 \\
Nurkent & 15 & 7,7 & 152 & 262.800 \\
Gazimahbup & 22 & 16,4 & 140 & 599.330 \\
Ata & 40 & 13 & 140 & 725.255 \\
Buğdaylı & 14 & 11,1 & 110 & 365.000 \\
TOPLAM & 490 & 263,4 & & 10.442 .465 \\
\hline
\end{tabular}

İlçede içme suyu amaçlı kuyulara ait tahsisli su miktarının $10.442 .465 \mathrm{~m}^{3} / \mathrm{yl}$ 'dır. Kuyu derinlikleri 110$160 \mathrm{~m}$ arasında değişmektedir. Karatepe ve Kara Mustafa Paşa kuyularının isale hattı olmadığı için işletmeye dâhil edilmediğinde belediyenin Merzifon konisi olarak adlandırılan yeraltı suyu alt havzasından çekeceği su miktarının $9.144 .345 \mathrm{~m}^{3} / \mathrm{y} 1$ olduğu görülmektedir. Kuyulara ait ruhsat verimlerinin güncel verimlerle karşılaştırıldığında zamanla yeraltı su seviyesi düşümüne bağlı olarak düştüğü görülmektedir. Kuyulardan ruhsatlarına göre 490 1/s su tahsisi yapılmakla birlikte fiili olarak 263,4 1/s su çekilebilmektedir.

Paşa Deresi ve Kuruçay Deresindeki yeraltı su seviyesindeki düşümler belediye tarafından 2013 yllında kuyu ve depo scada sistemi verilerinden de görülebilmektedir. Bu verilerden ilçenin içme suyunu temin ettiği Paşa deresi ve Kuruçay deresinin yeraltı su potansiyeli incelenmiş̧ir. Belediyenin içme ve kullanma suyu temininde kullandığı Paşa Deresi üzerindeki İtfaiye Kuyu'nun debi ve seviye değişimleri Tablo 5'da sunulmuştur. Seviye ve debi verilerinin mevsimsel faktörlerden etkilenmemesi için her bir yılın kasım ayına ait verileri alınmış̧ır. Paşa Deresi üzerindeki İtfaiye Kuyusu seviye verileri incelendiğinde, kuyudan 2013 yılında saatte $100 \mathrm{~m}^{3}$ su 40,70 m'den çekilebiliyorken, 2020 yılı kasım ayında $63 \mathrm{~m}^{3}$ su 74,00 m seviyesinden çekilmiştir. Debide $37 \mathrm{~m}^{3} / \mathrm{h}$ 'lik düşüş olurken, dinamik seviye $33,30 \mathrm{~m}$. düşmüştür

Tablo 5. İtfaiye kuyusu debi ve seviye verileri [18]

\begin{tabular}{ccc}
\hline Tarih & $\begin{array}{c}\text { Dinamik su seviyesi } \\
(\mathbf{m})\end{array}$ & $\begin{array}{c}\text { Debi } \\
\left(\mathbf{m}^{3} / \mathbf{h}\right)\end{array}$ \\
\hline Kasım 2013 & 40,70 & 100 \\
Kasım 2014 & 52,63 & 100 \\
Kasım 2015 & 54,39 & 100 \\
Kasım 2016 & 58,73 & 102 \\
Kasım 2017 & 60,00 & 78 \\
Kasım 2018 & 66,11 & 86 \\
Kasım 2019 & 70,00 & 73 \\
Kasım 2020 & 74,00 & 63 \\
\hline
\end{tabular}

Kuruçay Deresi üzerindeki alandaki yeraltı suyu seviyesinin gözlenebileceği Tübin kuyusu seviye ve debi verileri Tablo 6'de sunulmuştur. Kuyudan 2014 yllında saatte $85 \mathrm{~m}^{3}$ su $80,24 \mathrm{~m}$ seviyesinden çekilebiliyorken, 2020 yılı kasım ayında $70 \mathrm{~m}^{3}$ su 90,00 m. seviyesinden çekilmiştir. Debide $15 \mathrm{~m}^{3} / \mathrm{h}$ azalırken, dinamik seviye 9,76 m. düşmüştür. 


\begin{tabular}{|c|c|c|}
\hline & $\begin{array}{l}\text { BŞEÜ Fen Bilimleri Dergisi } \\
8(2), 990-1009,2021\end{array}$ & $\begin{array}{r}\text { BSEU Journal of Science } \\
\text { https://doi.org/10.35193/bseufbd } 987582\end{array}$ \\
\hline $\begin{array}{l}\text { BilEECISSEYHEDEBALI } \\
\text { UNIVERSITESI }\end{array}$ & & 2458-7575 (https://dergipark.org.tr/tr/pub/bseufbd) \\
\hline
\end{tabular}

Tablo 6. Tübin kuyusu debi ve seviye verileri [18]

\begin{tabular}{ccc}
\hline Tarih & $\begin{array}{c}\text { Dinamik su seviyesi } \\
(\mathbf{m})\end{array}$ & Debi $\left(\mathbf{m}^{\mathbf{3}} \mathbf{h}\right)$ \\
\hline Kasim 2014 & 80,24 & 85 \\
Kasim 2015 & 81,80 & 80 \\
Kasim 2016 & 84,84 & 80 \\
Kasim 2017 & 87,90 & 80 \\
Kasim 2018 & 92,61 & 80 \\
Kasim 2019 & 88,50 & 70 \\
Kasim 2020 & 90,00 & 70 \\
\hline
\end{tabular}

Kuruçay ve Paşa derelerinin oluşturduğu Merzifon konisinin alanı $94 * 10^{6} \mathrm{~m}^{2}$ 'dir. DSİ tarafından yapılan yeraltı suyu beslenim hesabında bu alana düşen yağışın \% 12'sinin yeraltına süzülerek yeraltı suyunu besleyeceği kabul edilmiştir. Yağış yoluyla yeraltı suyu rezervinin hesaplanmasında 1980 ve 2010 yılları arasındaki ortalama yağış değeri olarak $439 \mathrm{~mm}$ alınmıştır. Bu durumda Merzifon konisinden olan beslenim miktarı $94 * 10^{6} * 0,439 * 0,12=5 * 10^{6} \mathrm{~m}^{3} / \mathrm{y}$ ll olarak saptanmıștır. Yeraltı suyu rezervinin 5 milyon $\mathrm{m}^{3} / \mathrm{y} 1 \mathrm{l}$ iken, içme kullanma için 18,32 milyon $\mathrm{m}^{3} / \mathrm{y} 1 \mathrm{l}$, sanayi için 0,25 milyon $\mathrm{m}^{3} / \mathrm{y} 1$ l, sulama için 0,16 milyon $\mathrm{m}^{3} /$ yıl ve kooperatiflere yapılan tahsislerin 1,14 milyon $\mathrm{m}^{3} / \mathrm{y}$ l olmak üzere toplamda 19,88 milyon $\mathrm{m}^{3} / \mathrm{y}$ 1l olarak görülmektedir. Ayrıca belgesi olmadan yeraltı suyu kullanım miktarı ne kadar olduğu ile ilgili veri bulunmamaktadır. Merzifon konisi yenileme amacıyla açılacak içme suyu kuyuları hariç yeni açılacak içme suyu kuyuları için kuyu açılmasına kapalı bölge olarak belirlenmiştir. Mevcut kuyulardan gerçekleşen yıllık çekim miktarlarına ilişsin veri belediyeye ait kuyular dışında bulunmamaktadır. Beslenim miktarının üzerinde yeraltı suyu çekilmesi nedeniyle yeraltı su kaynağının hızlı bir şekilde yok olduğu görülmektedir.

Devlet Su İşleri (DSI) Genel Müdürlüğü 7. Bölge Müdürlüğünün Paşa ve Kuruçay Deresinin oluşturduğu koni olarak adlandırılan alanla ilgili teknik raporunda yer altı suyu kullanımındaki artış ve yaşanan kuraklıklar nedeniyle alüvyal dolgu yeraltı suyu besleniminin oldukça azaldığı, bölgede kısıtlı olan yer altı suyu rezervinin son derece kritik bir noktaya geldiği belirtilmiştir. 1990 yılından beri hızlı bir düşüş olduğu belirtilmiştir.

İlçenin mevcut su kaynaklarına bakıldığında yer altı su kaynaklarının ve kaynak sularının sürekli olarak debi ve seviye olarak düştüğü görülmektedir. Çekilen su miktarı yağışlarla yeraltı suyu beslenim miktarının üzerindedir. Su kaynaklarının her geçen gün azalmasıyla birlikte artan talebin karşılanmasında zorluklar çıkacağı ve mevcut yeraltı kaynağının kısa sürede biteceği açıkça görülmektedir.

2) İçme Suyu Şebekesinin İncelenmesi: İçme suyu şebekesi 1975 yılında İmar ve İskân Bakanlığınca onaylanan projeye göre İller Bankası tarafından yaptırılmıştır. 1979 yılında işletmeye açılmıştır. İçme suyu şebekesi üst-orta-alt kat olarak 3 kat olarak ayrılmıştır. Şebekenin yenilenmesi amacıyla İller Bankası Genel Müdürlüğü İçme Suyu Dairesi Başkanlığı tarafından 1999 tarihinde onaylanan içme suyu projesi inşaatı gerçekleştirilememiştir. Sonraki yıllarda belediye yerleşim alanlarının genişlemesiyle ortaya çıkan su talepleri için mevcut şebekesini genişletmiştir. Kuyulardan çekilen suların ve kaynak noktalarından temin edilen suların iletildiği borular 39.037 m’dir. Kaynak sularının iletim hatlarının çoğunluğunun 1988 ve 1991 yıllarında yapılmıştır. Kaynak sularının yetersiz kalmasıyla birlikte kuyulardan su temin edilerek basınçlı iletim hatlarının 2013 ve 2014 yıllarında yapıldığı görülmektedir. İletim hatlarında asbest borular bulunmaktadır.

İlçe su dağıtım sisteminde üç basınç bölgesi mevcuttur. Bu üç basınç bölgesindeki mahallelere hizmet veren beş depo ve iki yedek depo mevcuttur. Üst Kat, Orta Kat ve Alt Kat isimli depolar, yüksek, orta ve düşük basınca sahip üç farklı basınç bölgelerine hizmet vermektedir. Orta Kat 1 ve Orta Kat 2 depoları birbirine bağlıdır. Aynı durum Alt Kat 1 ve Alt Kat 2 depoları için de geçerlidir. Ahmet Demir deposu iki kaynaktan (Kayalık ve Musruf) gelen suyu toplamaktadır ve bunun bir kısmını Üst Kat basınç bölgesinde olan Yunus Emre Mahallesine iletmektedir. Sanayi Deposu Alt Kat basınç bölgesine hizmet vermektedir.

İlçeye su temin edilen depolardan üst kat, orta kat, alt kat depolarının yapım yılı dikkate alındığında, yapıldığı tarihten itibaren 2021 yılına kadar 42 yıl geçtiği görülmektedir. Su depoları hacimleri yersiz olup, su talebinin arttığı yaz aylarında ve çok kısa süreli elektrik kesintisinde bile boşalmaktadır. Su hizmetinin sürekliliği açısından su depolarının hacimlerinin büyütülmesi gerekmektedir. Ayrıca İlçe Sağlık Müdürlüğü tarafından yapılan denetimlerde de depolarda sızıntı olduğu, bu nedenle rutubet oluştuğu, su depolarının iç yüzeylerinin fayans, kalebodur, granit gibi yıkanabilir pürüzsüz malzeme ile kaplı olmadığı tespiti yapılarak; su depolarının iç yüzeylerinin fayans gibi kolay temizlenebilir malzemeden yapılması tavsiye edilmiştir. 
Belediye tarafından şebeke yapıldıktan sonraki yıllarda oluşan ihtiyaçlar doğrultusunda dağıtım ağı genişletilmiştir. Q80-Q450 mm çapları arasında değişen AÇB ve PVC borulardan oluşmaktadır. Su depolarından sonra oluşan su dağıtım sisteminde ana dağıtım boruları $15.996 \mathrm{~m}^{\text {asbest }}{ }^{1}$ hatlardan oluşmaktadır. Belediye tarafindan Kâşif Mercan Caddesi'ndeki 1.496 m AÇB hat, 2016 yılında 200 mm. 654 m, 160 mm. 516 m ve 140 mm. 326 m. olarak değiştirilmiștir. Dağıtım sistemi 132268 m PVC boru şebeke yapımı ile birlikte 1979 yılında yapılmıştır. Bundan sonraki yıllarda belediye tarafından şehrin genişlemesine paralel olarak boru döşenme işi gerçekleştirilmiştir.

Su şebekesini İller Bankası imar planı içerisindeki su ihtiyaç miktarına göre yapmıştır. Ancak şehrin çeşitli kısımlarına su dağıtımı yapıldığı görülmüştür. Bu alanlara döşenen borularla bağ evlerine hizmet götürülmekte ancak projede belirtilen basınç katları dışına çıkılarak basınçtan dolayı fiziki kayıplara neden olunmakta, ayrıca bu alanların sayaç okuma işlemleri düzenli olarak gerçekleştirilemediğinden kaçak su kullanımı artabilmektedir.

3) Su Şebekesinin Verimliliğinin İncelenmesi: Su şebekesinin verimliliğini incelemek amacıyla şebekeye verilen su miktarı, tahakkuk edilen su miktarı, ölçülen ancak tahakkuku yapılmayan su miktarları ve kayıp kaçak su miktarları incelenmiştir. İçme suyu şebekesine yıllık olarak verilen su miktarına ilişkin veriler belediyeye ait scada sisteminden alınmıştır. Belediye su abone yönetimi sisteminden faturalanan su miktarları tahakkuk edilen su miktarları olarak; ibadet yerleri, mahalle çeşmeleri, park alanları gibi belediyeye ait sosyal tesislerin kullandığı su miktarları faturalandırılmamış ölçülmüş kullanım olarak ve idari, fiziki kayıplar ile arızalardan kaynaklanan su kayıpları toplamı olarak da kayıp kaçak su adı altında Tablo 7'de sunulmaktadır.

Tablo 7. Su şebekesine verilen su miktarlarına ilişkin veriler $[17,18]$

\begin{tabular}{ccccc}
\hline Yıllar & $\begin{array}{c}\text { Sisteme verilen } \\
\text { su }\left(\mathbf{m}^{\mathbf{3}} / \mathbf{y ı l}\right)\end{array}$ & $\begin{array}{c}\text { Tahakkuk edilen su } \\
\left(\mathbf{m}^{\mathbf{3}} / \mathbf{y} \mathbf{l}\right)\end{array}$ & $\begin{array}{c}\text { Faturalandırılmamış } \\
\text { ölçülmüş kullanım } \\
\left(\mathbf{m}^{\mathbf{3}} / \mathbf{y l l}\right)\end{array}$ & $\begin{array}{c}\text { Toplam kayıp kaçak ve } \\
\text { ölçülmeyen su miktarı } \\
\left(\mathbf{m}^{\mathbf{3}} / \mathbf{y ı l}\right)\end{array}$ \\
\hline $\mathbf{2 0 1 7}$ & 6.623 .198 & 2.731 .866 & 259.960 & 3.631 .372 \\
$\mathbf{2 0 1 8}$ & 6.398 .109 & 2.974 .183 & 315.101 & 3.108 .825 \\
$\mathbf{2 0 1 9}$ & 6.262 .381 & 2.948 .818 & 182.796 & 3.130 .767 \\
$\mathbf{2 0 2 0}$ & 6.550 .634 & 3.190 .606 & 104.579 & 3.255 .449 \\
\hline
\end{tabular}

Tahakkuk edilen (gelir getiren) suyun toplam sisteme giren su miktarını 2017 yllında \% 41,2, 2018 yılında \% 46,5, 2019 yılında \% 47 ve 2020 yılında \% 48,7 olarak gerçekleştiği ve gelir getiren su miktarının bir sonraki yıla göre arttığı görülmektedir. Faturalandırılmamış ölçülmüşs su kullanımı ibadet yerleri, belediye tesisleri ve mahalle çeşmelerinde kullanılan su miktarın ifade ederken bu miktarın 2019 ve 2020 yıllarında muhtemelen pandeminin etkisiyle ortak alanlardaki su kullanımının azalmasıyla düştüğü ifade edilebilir. Tuna (1995) ve Lambert (2001) tarafından da vurgulandığı üzere, toplam kayıp kaçak su şebekesindeki fiziki kayıpları (su temin ve dağıtım sistemindeki kayıplar ve depolarda meydana gelen sızıntı, taşma gibi kayıpları), su sayaçlarının hassasiyet düzeyi nedeniyle oluşan kayıpları, sayaç verilerinin işlenmesindeki hataları, izinsiz kaçak su kullanımını (su abone bağlantı borusuna yasal olmayan bağlantı yapılarak) ifade ederken; ölçülmeyen su miktarı arızaların tamiratı sırasında kaybolan suyu, yangın hidratlarından alınan su, boru hatları veya armatürlerin (vana, vantuz gibi) bakımları sırasında tahliye edilen su gibi kullanılan suyu ifade etmektedir. Toplam kayıp kaçak ve ölçülmeyen su miktarı toplam sisteme verilen su miktarının 2017 yılında $\%$ 54,8, 2018'de 48,6, 2019'da \% 50, 2020 'de \% 49,7'sini oluşturmaktadır.

Su şebekesindeki ana borularının AÇB olması ve dağıtım ağlarının eski olması nedeniyle ana boru ve abone bağlantı hatlarında arızalar meydana gelmektedir. 2016-2020 yıllarına ait bildirilen su arıza sayılarında artış eğiliminin olduğu ve bunun hatları yapım yılı ile ilişkili olduğu tespit edilmiştir. Tablo 8'de 2016-2020 yıllarında bildirilen su arıza sayıları sunulmuştur.

\footnotetext{
${ }^{1}$ Asbest, doğal olarak ortaya çıkan çeşitli lifli silikatlara verilen addır. 20. Yüzyılın başlarında asbestli çimento üretilmesiyle asbest kullanımı tüm dünyada yayılmıștır. Uluslararası Çalışma Örgütü verilerine göre dünyada 125 milyon kişi çalışma ortamlarında asbeste maruz kaldığı ve her yıl 100.000 kişinin çalışma ortamlarında asbeste maruz kalmalarının yol açtı̆̆ı hastalıklar nedeniyle öldüğü belirtilmiştir. Türkiye'de asbest kullanımı 29.08.2010 tarihli ve 27687 sayılı resmi gazete ile 30.12.2010 tarihinden itibaren liflerinin çıkarılamayacağı, herhangi bir ürünün üretiminde ve üretim dışında bir amaçla kullanılamayacağı, satış ve kullanım amacıyla piyasaya arz edilemeyeceği belirtilmiştir.
} 


\begin{tabular}{|c|c|c|}
\hline & $\begin{array}{l}\text { BŞEÜ Fen Bilimleri Dergisi } \\
8(2), 990-1009,2021\end{array}$ & $\begin{array}{r}\text { BSEU Journal of Science } \\
\text { https://doi.org/10.35193/bseufbd } 987582\end{array}$ \\
\hline & & 2458-7575 (https://dergipark.org.tr/tr/pub/bseufbd) \\
\hline
\end{tabular}

Tablo 8. Bildirilen su arıza sayıları [19]

\begin{tabular}{ccc}
\hline Yıllar & $\begin{array}{c}\text { Ana Boru Arıları } \\
\text { (Adet) }\end{array}$ & $\begin{array}{c}\text { Abone Bağlantı Arızaları } \\
\text { (Adet) }\end{array}$ \\
\hline $\mathbf{2 0 1 6}$ & 132 & 541 \\
$\mathbf{2 0 1 7}$ & 143 & 591 \\
$\mathbf{2 0 1 8}$ & 148 & 719 \\
$\mathbf{2 0 1 9}$ & 164 & 563 \\
$\mathbf{2 0 2 0}$ & 146 & 621 \\
\hline
\end{tabular}

Asbest çimentolu borulardaki (AÇB) arızalar genellikle boru başlarındaki contaların fonksiyonunu yerine getirememesi, diğer PVC dağıtım borularındaki arızalar borunun kırılması ve abone bağlantılarındaki arızalar boru ek noktalarından ve boru kırılmalarından oluşmaktadır. AÇB boru arızaları tamiratı kolay tamir kelepçeleriyle yapılmakta, arıza tamiratından sonra başka bir noktadan AÇB borudan arıza oluştuğu gözlenmektedir. Ayrıca ana boru arızalarının tamiratından sonra abone bağlantısı arızalarının sayısında da artış olmaktadır. $\mathrm{Bu}$ arızaların tespiti, kazılarak tamiratının yapılması sırasında da su kayıpları yoğun şekilde yaşanmaktadır. Arızalardan bildirilen arızalar belediyeye bırakılan arıza şikâyetlerinden, bildirilmeyen arızalar ise dinleme cihazı ile boru hatları dinlenmesiyle kayıp kaçak tespiti yapılarak bulunarak tamiratı yapılmaktadır. Belediye fiziki kayıp kaçak ekiplerinin 2018 yılında kurulmasıyla birlikte tespit edilen (bildirilmemiş) ana boru ve abone bağlantı arızalarının sayıları Tablo 9'de sunulmaktadır.

Tablo 9. Bildirilmeyen (tespit edilen) su arıza sayıları [19]

\begin{tabular}{ccc}
\hline Yıllar & $\begin{array}{c}\text { Ana Boru Arıları } \\
\text { (Adet) }\end{array}$ & $\begin{array}{c}\text { Abone Bağlantı Arızaları } \\
\text { (Adet) }\end{array}$ \\
\hline $\mathbf{2 0 1 8}$ & 14 & 57 \\
$\mathbf{2 0 1 9}$ & 14 & 27 \\
$\mathbf{2 0 2 0}$ & 13 & 35 \\
\hline
\end{tabular}

Bildirilen ve bildirilmeyen su arıza sayılarına bakıldığında 2016'da 673, 2017'de 734, 2018'de 938, 2019'da 768, 2020'de ise 815 arıza tamiratı yapıldığı görülmektedir. Bu arızaların tamiratı sırasında malzeme, iş makinası, işçilik, bozulan yolun tamiratı gibi maliyetlerin yanında, kaybolan su da bulunmaktadır. Sisteme verilen su kaynak suları ve kuyulardan çekilen sulardan oluşmakta olup, suyun kuyulardan çıkarılmasında kullanılan 2016-2020 yıllarına ait elektrik enerjisi miktarı ve birim $\mathrm{m}^{3}$ başına kullanılan enerji miktarı Tablo 10'de sunulmuştur.

Tablo 10. Su çekiminde kullanılan enerji miktarları $[16,17,18]$

\begin{tabular}{cccc}
\hline Yıllar & Enerji Miktarı (kwh) & Sisteme Giren Su $\left(\mathbf{m}^{\mathbf{3}}\right)$ & $\begin{array}{c}\text { Suyun Çıkarma Maliyeti } \\
\left(\mathbf{k w h} / \mathbf{m}^{3}\right)\end{array}$ \\
\hline $\mathbf{2 0 1 7}$ & 3.906 .217 & 6.623 .198 & 0,59 \\
$\mathbf{2 0 1 8}$ & 3.969 .112 & 6.398 .109 & 0,62 \\
$\mathbf{2 0 1 9}$ & 3.995 .907 & 6.262 .381 & 0,64 \\
$\mathbf{2 0 2 0}$ & 4.967 .923 & 6.550 .634 & 0,76 \\
\hline
\end{tabular}

Sisteme verilen suyun 2017-2020 yılları arasında $6.623 .198 \mathrm{~m}^{3}$ 'den $6.550 .634 \mathrm{~m}^{3}$ 'e gerilemesine rağmen, kullanılan elektrik enerjisi miktarının arttığı görülmektedir. Kuyu seviyelerinin düşmesi nedeniyle ve yağışların azalmasıyla kaynak sularının miktarının azalmasıyla yeraltı suyundan yapılan çekimde artmakta dolayısıyla elektrik gideri de artmaktadır. 2017 yılında $0,59 \mathrm{kwh} / \mathrm{m}^{3}$ olan suyun çıkarılma maliyeti \%28,8 artarak 2020 yılında $0,76 \mathrm{kwh} / \mathrm{m}^{3}$ olarak gerçekleşmiştir.

\section{Su Abone Verilerinin İncelenmesi}

$\mathrm{Bu}$ kısımda su abone tiplerine ilişkin veriler, su faturalarına yansıtılan ücretler ve su tahakkuk tahsilata ilişkin veriler incelenmiştir.

1) Su Abone Tiplerine Ilişkin Verilerin Incelenmesi: Su abonelikleri su ve kanalizasyon idaresi tarafından yapılmaktadır. Aboneler tarafından su sayaçları alınarak belediye tahakkuk servisine getirilmekte, abonelik işlemi tamamlandıktan sonra sayaç takma işlemi gerçekleşmektedir. Mekanik su sayacı kullanan abonelerinin harcadıkları su miktarları, aylık olarak düzenli şekilde el terminalleri ile okunmaktadır. Belediye Meclisi'nin 05.10.2010 tarihli ve 80-2010 sayılı kararı ile su gelirlerinin artırılması, mülk sahibi kiracı problemlerinin ortadan 


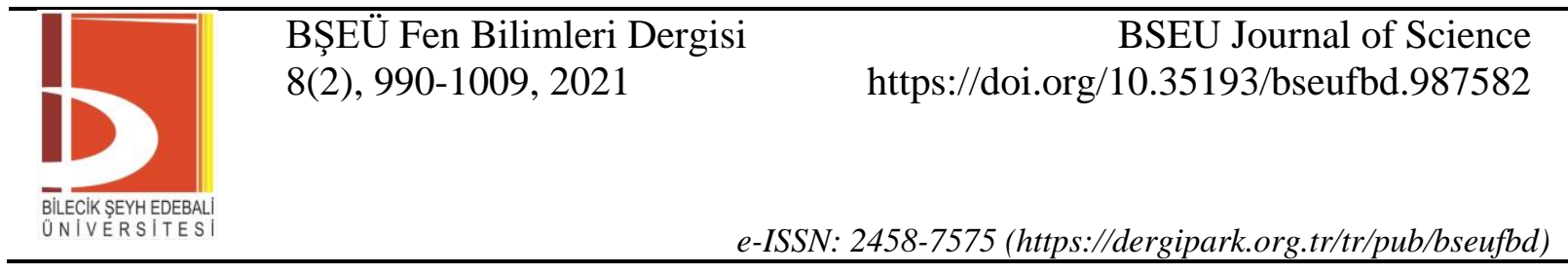

kaldırılması amacıyla ön ödemeli kartlı su sayacına geçilmiştir. Ancak aboneliklerin bu sayaç tipini tercih etmemesi nedeniyle 07.02.2012 tarih ve 17-2012 sayılı kararla yeni içme suyu abonesi yaptıracak tüm abonelerde ön ödemeli kartlı su sayacı zorunlu tutulmuştur. Ayrıca mevcut mesken abonelerinden ön ödemeli kartlı sayaca geçenlere $20 \mathrm{~m}^{3}$ su verilmesi kararlaştırılmıştır. 31.12.2020 tarihi itibariyle abone tipleri ve sayıları Tablo 11'de, 2011-2020 yılları arasındaki abone artış miktarları ise Tablo 12'de sunulmaktadır.

Tablo 11. Abone tipleri ve saylları [17]

\begin{tabular}{cc}
\hline Abone Tipi & Abone Sayıs \\
\hline Meskenler & 28.154 \\
Ticarethane & 2694 \\
Resmi & 151 \\
İnşaat & 520 \\
Hamam & 4 \\
Bankalar & 10 \\
Bağ-bahçe & 251 \\
Şehit ailesi, gazi, özürlü & 644 \\
OSB & 2 \\
Yurt & 1 \\
Faturasız & 134 \\
Geçici kapalı, İptal & 2588 \\
Toplam & 35153 \\
\hline
\end{tabular}

Tablo 12. Abone sayısı artış miktarları [17]

\begin{tabular}{cccc}
\hline Yıllar & $\begin{array}{c}\text { Yeni abone } \\
\text { sayısı }\end{array}$ & $\begin{array}{c}\text { Abone } \\
\text { sayıları }\end{array}$ & Artış oranları (\%) \\
\hline 2011 yılı öncesi & - & 24253 & - \\
2012 & 835 & 25088 & 3,4 \\
2013 & 942 & 26030 & 3,8 \\
2014 & 1120 & 27150 & 4,3 \\
2015 & 1200 & 28350 & 4,2 \\
2016 & 1361 & 29711 & 4,6 \\
2017 & 1455 & 31166 & 4,9 \\
2018 & 1714 & 32880 & 5,5 \\
2019 & 1093 & 33973 & 3,3 \\
2020 & 1180 & 35153 & 3,5 \\
\hline
\end{tabular}

31.12.2020 tarihi itibariyle toplam 35153 abone bulunmaktadır. Abonelerin \% 80,09'u mesken, \%7,66’s1 ticarethane, \%1,48'i inşaat, \% 1,83'ü şehit ailesi özürlü, \% 7,36'sı geçici kapalı iptal tiplerini oluşturmaktadır. Abone sayıları yıllara göre bakıldığında 2011 yılından itibaren ortalama olarak \% 4,7 artmıştır. İçme suyu abonelerinde kullanılan sayaçlar mekanik ve ön ödemeli elektronik sayaçlardır. Ön ödemeli sayaç sayısı 12493, mekanik sayaç sayısı 22660 adettir. Ön ödemeli sayaçlar toplam sayaçların \% 35, 5'ini oluşturmaktadır.

Ön ödemeli kartlı su sayacında aboneler satın aldıkları kredi tutarında su kullanabilmektedir. Sayaç okuma işlemi yapılmamaktadır. Fatura hazırlama ve dağıtım işlemleri olmamaktadır. Ödenmeyen fatura sorunu olmamaktadır. Ön ödemeli kartlı su sayaçlarının yüklenen kredisi bittiğinde vananın kesmediği durumlarda, mekanik endeksin ilerlediği, bu sayaçların tespit edilmesi gerektiği bildirilmiştir. Ayrıca bu sayaçların tespiti ardından fabrikasına gönderilerek tamiratının yapılması arasında süre geçtiği, bu sürede aboneye mekanik sayaç takılarak tahakkuk yapılmaktadır. Sayaç ücretinin mekanik sayaçlara göre 5-6 kat fazla olması ve tamirat ücretinin mekanik sayaç ücretinin 2 katına kadar çıkabilmesi abonelerin ikna edilmesinde problem olduğu görülmüştür. Bu sayaçlardan belirli markaların sayaçlarının çok fazla vana arızası yaparak kesmediği, eksiye düşerek işleyişi aksattığı bildirilmiştir. Elektronik ön ödemeli kartlı su sayaç sisteminin ön ödeme yapılması ile tahsilatı hızlandırması dışında işletme maliyetinin yüksek olduğu görülmüştür.

2) Su Faturalarına Yansitılan Ücretler: Belediyeye ait tarifeler Mali Hizmetler Müdürlüğü Gelir Şefliği tarafından oluşturulmaktadır. Birimlerden alınan maliyete ilişkin veriler eşliğinde Gelir Komisyonu tarafından altı aylık dönemler halinde kararlaştırılarak belediye meclisinde onaylanmaktadır. Gelir tarifelerinde su ve atık su hizmetlerine ilişkin olarak içme suyu, kartlı sistem içme suyu, içme suyu teminatları, içme suyu abonelik, abone yaptırmadan su kullananlardan alınacak ücretler ve atık su toplama, arıtma ve bertaraf ücret tarifeleri bulunmaktadır. En düşük tarife olan “Meskenler”in 2012 ve 2021 yılları arasındaki $1 \mathrm{~m}^{3}$ su fiyatı Tablo 13'de sunulmaktadir. 


\begin{tabular}{|c|c|c|}
\hline & $\begin{array}{l}\text { BŞEÜ Fen Bilimleri Dergisi } \\
8(2), 990-1009,2021\end{array}$ & $\begin{array}{r}\text { BSEU Journal of Science } \\
\text { https://doi.org/10.35193/bseufbd } 987582\end{array}$ \\
\hline & & 2458-7575 (https://dergipark.org.tr/tr/pub/bseufbd) \\
\hline
\end{tabular}

Tablo 13. Mesken aboneliğine ait uygulanan birim $\mathrm{m}^{3}$ su fiyatları $[17,19]$

\begin{tabular}{cccccc}
\hline Yıllar & $\begin{array}{c}\text { Ocak Yİ-ÜFE } \\
\text { değerleri }\end{array}$ & $\begin{array}{c}\text { 1.Tarife } \\
\text { (mekanik sayaçlı } \\
\text { abonelerde) }\end{array}$ & $\begin{array}{c}\text { Güncel değer } \\
\text { (2021 Ocak } \\
\text { endekslerine göre) }\end{array}$ & $\begin{array}{c}\text { Tek tarife } \\
\text { (Ön ödemeli } \\
\text { abonelerde) }\end{array}$ & $\begin{array}{c}\text { Güncel değer } \\
\text { (2021 Ocak } \\
\text { endekslerine } \\
\text { göre)3 }\end{array}$ \\
\hline 2021 & 583,38 & 3,75 & 3,75 & 3,60 & \\
2020 & 462,42 & 3,00 & 3,79 & 2,50 & 3,15 \\
2019 & 424,86 & 3,00 & 4,12 & 2,50 & 3,43 \\
2018 & 319,60 & 2,50 & 4,56 & 2,20 & 4,02 \\
2017 & 284,99 & 2,50 & 5,12 & 2,20 & 4,50 \\
2016 & 250,67 & 2,30 & 5,35 & 2,00 & 4,65 \\
2015 & 236,61 & 2,30 & 5,67 & 2,30 & 5,67 \\
2014 & 229,10 & 2,10 & 5,35 & 2,10 & 5,35 \\
2013 & 206,91 & 2,10 & 5,92 & 2,10 & 5,92 \\
2012 & 203,10 & 1,90 & 5,46 & 1,90 & 5,46 \\
2011 & 182,75 & 1,70 & 5,43 & 1,70 & 5,43 \\
2010 & 164,94 & 1,70 & 6,01 & 1,70 & 6,01 \\
\hline
\end{tabular}

Su birim $\mathrm{m}^{3}$ fiyatları incelendiğinde; her yıl uygulanan tarifeler Yİ-ÜFE endeks değerlerine göre 2021 Ocak ayına getirilmiştir. Mekanik sayaçlı aboneler için güncel değerlere bakıldığında en yüksek birinci tarifede $6,01 \mathrm{TL} / \mathrm{m}^{3}$ ile 2010 yılı olduğu görülmektedir. Ön ödemeli abonelere uygulanan tarifeye bakıldığında $6,01 \mathrm{TL} / \mathrm{m}^{3}$ ile 2010 yılı su fiyatı en yüksektir. 2020 yılı ocak ayına güncellenen su birim fiyatlarına bakıldığında mekanik sayaç kullanan abonelerin birinci kademede bulunan tarifesinin 2011 ve 2017 yılları arasındaki güncel değerinin 5,12-5,92 TL arasında değişirken, 2017 yılından sonra düştüğü görülmektedir. Benzer şekilde ön ödemeli sayaçlı abonelerin su birim fiyatları incelendiğinde 2016 yılından itibaren güncel değerinin düştüğü enflasyon oranı artışının yansıtılmadığı görülmektedir. Tablo 14 'de birim $\mathrm{m}^{3}$ atık su bertaraf fiyatı sunulmaktadır.

Tablo 14. Meskenler abone tipine ait atık su birim bertaraf $\mathrm{m}^{3}$ fiyatları $[17,19]$

\begin{tabular}{|c|c|c|c|}
\hline Yillar & $\begin{array}{c}\text { Ocak Yİ-ÜFE } \\
\text { değerleri }\end{array}$ & $\begin{array}{l}\text { Atık su birim fiyatı } \\
\left(\mathrm{TL} / \mathrm{m}^{3}\right)\end{array}$ & $\begin{array}{c}\text { Güncel değer } \\
\text { (2021 Ocak endekslerine göre) }\end{array}$ \\
\hline 2021 & 583,38 & 1,25 & 1,25 \\
\hline 2020 & 462,42 & 0,75 & 0,95 \\
\hline 2019 & 424,86 & 0,70 & 0,96 \\
\hline 2018 & 319,6 & 0,46 & 0,84 \\
\hline
\end{tabular}

Atık su birim m³ fiyatının 2018 yılında 0,46 TL iken 2021 yılında 1,25 olarak belirlendiği görülmektedir. 2021 yılı ocak ayına güncellenen değerler incelendiğinde 2018 yılından 2021 yılına kadar \% 48.9'luk bir artış görülmektedir.

Türkiye'de içmesuyu, sulama ve kullanma suyu ile atıksu arıtma tesislerindeki maliyet analizi ve fiyatlandırma sistemleri yeterince gelişmemiştir [1,8-10,23]. Atıksu arıtma maliyetlerinin analizi, fiyatlandırma ve fiyat artışlarını gösteren maliyet indekslerinin geliştirilmesi ve kullanılmasında birçok sorun bulunmakta ve bu amaçla geliştirilen metodoloji paket programların birçok kentte kullanılamadığı bilinmektedir [10,20,21,23]. İncelenen kentte su, atıksu maliyet analizi ve fiyalandırma alanında da önemli sorunların olduğu görülmektedir.

Kentlerde genellikle içme ve kullanma suyu ücretlerine ait tarifeler abone tiplerine göre oluşturulması tercih edilmektedir [19-22]. Mekanik sayaç kullanan ve elektronik ön ödenmeli kartlı sayaç kullanan aboneliklerin tarifeleri farklılaştırılmıştır. Mekanik sayaçlı abonelerde $50 \mathrm{~m}^{3}$ 'den sonra kademelendirme yapılmakta iken, ön ödemeli sayaç kullanan abonelerde kademeli tarife bulunmamaktadır. Engelli kimlik kartı olanlar ve ilçede ikamet eden şehit dul ve yetimlerinden abone kendi adına olmak kaydıyla \% 50 indirimli tarife uygulanmaktadır. Mekanik sayaçlı abonelerden aylık olarak abone bakım ücreti olarak sabit bir ücret alınmaktadır. Aylık su sarfiyatı olmadığ durumlarda bu ücret alınmamaktadır. İçme suyu ücretlerine ait 2020 yılında aylık olarak uygulanan tarife Tablo 15 'de sunulmaktadır. 


\begin{tabular}{|c|c|c|}
\hline & $\begin{array}{l}\text { BŞEÜ Fen Bilimleri Dergisi } \\
8(2), 990-1009,2021\end{array}$ & $\begin{array}{r}\text { BSEU Journal of Science } \\
\text { https://doi.org/10.35193/bseufbd } 987582\end{array}$ \\
\hline $\begin{array}{l}\text { BilEECISSEYHEDEBALI } \\
\text { UNIVERSITESI }\end{array}$ & & 2458-7575 (https://dergipark.org.tr/tr/pub/bseufbd) \\
\hline
\end{tabular}

Tablo 15. İçme suyu tarifeleri $[17,19]$

\begin{tabular}{ccc}
\hline Abone tipleri & $\begin{array}{c}\text { Mekanik sayaçlarda (Ücret } \\
\left.\mathbf{T L} / \mathbf{m}^{3}\right)\end{array}$ & $\begin{array}{c}\text { Ön ödemeli sayaçlarda } \\
\left(\mathbf{U} \mathbf{c r e t} \mathbf{~ T L} / \mathbf{m}^{3}\right)\end{array}$ \\
\hline Meskenler & $3,00\left(50 \mathrm{~m}^{3}\right.$ sonras1 6,60$)$ & 2,50 \\
Resmi kurumlar & 3,30 & \\
Ticarethaneler & $4,00\left(50 \mathrm{~m}^{3}\right.$ sonrası 7,25$)$ & 4,00 \\
Organize Sanayi Bölgesi & 3,00 & 4,00 \\
Hamamlar & 4,00 & 15,00 \\
Bankalar & 15,00 & 11,00 \\
İşaatlar & 11,00 & 6,00 \\
Bağ-bahçeler & $8,00\left(30 \mathrm{~m}^{3}\right.$ üzeri 35,00$)$ & \\
\hline
\end{tabular}

İçme suyu tarifelerine bakıldığında abone gruplarının mesken, ticarethane, resmi abone grupları şeklinde daha sade bir yapıya dönüştürülebileceği görülmektedir. Su tüketiminde uygulanan $50 \mathrm{~m}^{3}$ üzeri su tüketimi için kademelendirme uygulamasının tüketim miktarlarının daraltılarak gerçekleștirlmesi suyun daha verimli kullanılmasını sağlayacaktır. Ön ödemeli sayaçlara kademelendirme uygulanamaması bir eksiklik olarak görülmektedir.

Abone yaptırmadan su kullananlar, mühürün kopartılması, ana su borusuna zarar verenlere cezai işlem uygulanmaktadır. Kaçak su kullanan tespit edilerek belediye encümeni tarafindan uygulanacak ceza tutarı belirlenmektedir. Arızalı su sayaçlarında bir yıllık ortalama su sarfiyatı üzerinden tahakkuk gerçekleştirilmektedir. Su ve kanalizasyon abone bağlantılarında iş makinesi, asfalt bozma ücreti, işçilik ücreti alınmaktadır. Bu talep üzerine inşaat abonelerine ve su veya kanalizasyon hattı eskiyen binalara uygulanmaktadır. İnşaatlardan inşaat ruhsatı esnasında İmar ve Şehircilik müdürlüğü tarafından su kanalizasyon harcamalarına katılma payı alınmaktadır.

İçme suyu faturalarına ayrı bir kalem olarak çöp toplama hizmetlerine ilişkin ücretlerde eklenerek alınmaktadır. Çevre Temizlik Vergisi $\mathrm{m}^{3}$ başına 2021 yılında 19 kuruş olarak alınmaktadır. Ayrıca belediye katı atıklarını il ve ilçe belediyeleri tarafından kurulan katı atık birliğine teslim etmektedir. İlçede çöpler toplanarak transfer merkezine getirilmekte buradan katı atık birliğine götürülmektedir. Bu hizmetlerin karşıllı̆ı olarak da su faturalarına katı atık ücreti olarak kullanılan su miktarı üzerinden $\mathrm{m}^{3}$ başına meskenlerden ve ticarethanelerden $0,50 \mathrm{TL}$, resmi kurumlardan 0,65 TL ücret tahakkuk ettirmektedir.

Su faturaları üzerinde su, atık su, çevre temizlik vergisi ve katı atık ücreti dışında bunlara ait vergilerde alınmaktadır. Gerçekleştirilen katı atık toplama, taşıma ve bertaraf faaliyetleri nedeniyle katı atık ücreti üzerinden \% $18 \mathrm{KDV}$ hesaplanmaktadır. Su ve atık su faaliyetleri nedeniyle de su ücreti ve atık su ücreti üzerinden de $\% 8$ KDV hesaplanmaktadır.

İçme suyu fiyatlandırması Belediye Meclisi yetkisinde olup, mevcut maliyet kalemlerinin hangilerinin yansıtıldığına ilişkin düzenleme bulunmamaktadır. Atık su ücretlerinin belirlenmesine yönelik Atık Su Altyapı ve Evsel Katı Atık Bertaraf Tesisleri Tarifelerinin Belirlenmesinde Uyulacak Usul ve Esaslara İlişkin Yönetmelik ile Atık su Tarifelerinin Belirlenmesine Yönelik Kılavuz yayımlanmıştır. Ancak belediye meclisleri bu tarifelerin belirlenmesinde karar ve onay makamı durumundadır. İçme suyu ve atık su fiyatlandırmasında finansal giderleri dahil işletme giderlerine ilave olarak sermaye, kaynak ve çevresel maliyetlerin de dikkate alınması ve tam maliyetlendirme esasına dayalı fiyatlandırma sistemlerinin geliştirilmesi, su kaynaklarının gelecek nesillere aktarılmasında büyük katkı sağlayacaktır. Bunun uygulanmasıyla ortaya çıkabilecek fiyat artışlarının yoksul aileler tarafından karşılanabilmesi için yerel bazda ödeyebilirlik analizlerinin yapılması, belediye meclislerinin suyun gerçek maliyetini karşılayabilecek abonelere de suyu değersizleştiren fiyatlandırma uygulamalarının önüne geçecektir.

3) Su Tahakkuk Tahsilat Verilerinin Incelenmesi: 2019 ve 2020 yıllarına ait tahakkuk ve tahsilat karşılaş̧ırması Tablo 16'de sunulmuştur. Değerler 2019 ve 2020 yllı sonu itibariyle üretilen su miktarı, tahakkuk eden su miktarı, gelir getirmeyen su miktarı, gerçekleşen tahakkuk (vergiler dahil), tahsilat ve gerçekleşen tahsilat oranından oluşmaktadır. Tahakkuk eden su miktarı 2019 yılında üretilen suyun \% 47,09'u olarak gerçekleşmişken, 2020 yılında üretilen suyun \% 48,70'i olarak gerçekleşmiştir. Tahsilatın tahakkuka oranı 2019'da \% 85,6 iken, bu oranın 2020 yılında \% 90,20’ye çıktı̆̆ı görülmektedir. 


\begin{tabular}{|c|c|c|}
\hline & $\begin{array}{l}\text { BŞEÜ Fen Bilimleri Dergisi } \\
8(2), 990-1009,2021\end{array}$ & $\begin{array}{r}\text { BSEU Journal of Science } \\
\text { https://doi.org/10.35193/bseufbd } 987582\end{array}$ \\
\hline $\begin{array}{l}\text { BilEECISSEYHEDEBALI } \\
\text { UNIVERSITESI }\end{array}$ & & 2458-7575 (https://dergipark.org.tr/tr/pub/bseufbd) \\
\hline
\end{tabular}

Tablo 16. Tahakkuk tahsilat karşılaştırması $[17,18]$

\begin{tabular}{ccc}
\hline Göstergeler & $\mathbf{2 0 1 9}$ & $\mathbf{2 0 2 0}$ \\
\hline Üretilen su miktarı $\left(\mathrm{m}^{3}\right)$ & 6.262 .381 & 6.550 .634 \\
Tahakkuk eden su miktarı $\left(\mathrm{m}^{3}\right)$ & 2.948 .818 & 3.190 .606 \\
Tahakkuk eden su \%'si & 47,09 & 48,70 \\
Gelir getirmeyen su \%'si & 52,91 & 51,3 \\
Tahakkuk miktarı (TL) & $12.042 .351,50$ & $13.779 .891,48$ \\
Tahsilat miktarı (TL) & $10.309 .248,04$ & $12.429 .779,26$ \\
Tahsilat oranı (\%) & 85,6 & 90,2 \\
\hline
\end{tabular}

Üretilen su miktarı ile tahakkuk eden su miktarı arasındaki fark oldukça yüksektir. Gelir getirmeyen suyun üretilen su miktarının 2019 yılı için \% 52, 91'i olduğu, 2020 yılı için \% 51, 3’ü olduğu görülmektedir. Gelir getirmeyen suyu oluşturan kayıp kaçak oranlarının düşürülmesine ilişkin planlama yapılmalıdır. Tahsilat oranının 2019 yılında tahakukun \% 85, 6'sını, 2020 yılında \% 90, 2'sini oluşturduğu görülmektedir. Tahsilatın tahakkuka oranının yüzde olarak yüksek olduğu tespit edilmiştir.

\section{Atıksu Hizmetlerinin İncelenmesi}

Bu kısımda şehir kanalizasyon sistemi ve atık su arıııı sistemi incelenmiştir. Mevcut kanalizasyon şebekesinin durumu, kanalizasyon arızaların nedenleri, atıksu arıtma tesisinin işleyişi değerlendirilmiştir.

1) Kanalizasyon sisteminin incelenmesi: Merzifon kanalizasyon inşaatı 2006 yllında İller Bankası tarafından tamamlanmıştır. Sözleşme kapsamında şebeke, toplayıcı ve kolektör hatları inşaatı, bu hatlara ait muayene bacaları ile parsel baca ve bağlantıları inşaatı yapılmıştır. Kanalizasyon şebekesi atık su arıtma tesisi alanına kadar yapılmış durumdadır. Toplanan atık su, $800 \mathrm{~mm}$. çaplı kolektör yoluyla bir noktadan Paşa Deresine deşarj edilmekte iken, 2018 yılı itibariyle atık su arıtma tesisine iletilmektedir. Kanalizasyon şebekesinde pompa istasyonu bulunmamaktadır, atık su tamamen cazibeyle toplanmaktadır. Kanalizasyon sistemi ayrık sistemdir. 2028 'de 125.000 kişilik bir nüfusa tasarlanıp inşa edilmiştir. 2025 ve 2040 gelişme alanlarını kapsayacak kademelendirme yapılmıştır.

Kanalizasyon şebekesi inşaatının tamamlanması ardından eski kanalizasyon sistemi yağmur suyuna terk edilmiştir. Ancak binaların tamamı yeni kanalizasyon şebekesine bağlanmamıştır. Bodrum katlarının giderlerinin kurtarmadığı binaların bağlantıları eski kanalizasyon sistemine bağlı kalmıştır. Bu sisteme bağlı binalarda şiddetli yağış olduğu zamanlarda su baskınları oluşabilmektedir.

Kanalizasyon sisteminde oluşan arızalara vidanjörle müdahale edilmektedir. Meydana gelen arızaların tamamına yakınının ıslak mendil kullanımı ve yağların birikmesi nedeniyle boru çapını daraltmasında meydana geldiği görülmüștür. Ayrıca sağanak yağışlı havalarda kanalizasyonun geri vurarak su baskınlarına neden olmaktadır. Bina yağmur su giderlerinin kanalizasyon sistemine bağlı olduğu ve yağışlı havalarda sadece atık su hesaplanarak yapılan kanalizasyon sisteminin bu durumu kaldırmadığından su baskınları ortaya çıkmaktadır. Arıza ekipleri arıza oluştuğunda ilgili yere giderek arızayı gidermektedir. Ancak kanalizasyon ana şebeke arızalarında kanalizasyon muayene baca kapakları asfalt altında kaldığından, asfaltın kırılıp kapağın açılarak müdahale edilmesinin zaman almaktadır. Ayrıca bina parsel bacalarının da kaldırım altında kaldığı, müdahaleyi geciktirmektedir. İlçe kanalizasyon sisteminde 2015 yılında 1152, 2016 yılında 1392, 2017 yllında 1011, 2018 yılında 741, 2019 yılında 1349, 2020 yılında 1234 adet ana hat ve abone tıkanıklığı gerçekleşmiştir. Kanalizasyon arıza ekiplerince bu arızalara müdahale edilmiştir.

İlçenin kanalizasyon şebekesinin muayene bacalarının tespit edilerek, kapakların bulunması ve yol seviyesine yükseltilmesi arızaya müdahale süresini kısaltacaktır. Ayrıca ana hatlar üzerinde sadece arıza olduğunda arıza giderilmesine yönelik çalışma yeterli olmadığı tespit edilmiş olup, periyodik olarak ana hatların vidanjörle temizlenmesi gerekmektedir. Bunun için arıza ekibi haricinde ekip oluşturulması gerekmektedir. $\mathrm{Bu}$ sayede acil çıkabilecek arıza sayısı minimum düzeye inecektir.

2) Atıksu arıtma sisteminin incelenmesi: Kanalizasyon inşaatı projesinde kentsel kanalizasyon sularının toplandığı alan belirlenerek atık su arıtma tesisi alanı olarak belirlenmiştir. Bu alan 2005 yılında belediye tarafından kamulaştırılmıştır. 2008 yılında Çevre ve Şehircilik Bakanlığı ile Merzifon Belediyesi arasında yapılan protokolle Merzifon Atık Su Arıtma Tesisi Projesi, Avrupa Birliği tarafından sağlanan mali yardım kapsamında finanse edilen Türkiye'de 15 Belediye İçin Atık su Arıtma Tesisi Projeleri Hazırlamaya Yönelik Teknik Yardım Projesi'nde yer alan projelerden biri olmuştur. Proje 2025 yılında 72.000 kişiye, 2040 yilında 93.825 kişiye hizmet edecek şekilde tasarlanmıştır. Tesis ilk etapta 2025 yılı ihtiyaçlarına göre planlanmıştır. İkinci etapta eklenecek 
ünitelerle birlikte 2040 yılında da hizmet verecektir. 2025 yılında arıtılacak su miktarı günde yaklaşık $9.000 \mathrm{~m}^{3}$, yıllık 3.5 milyon $\mathrm{m}^{3}, 2040$ yılında günde yaklaşık $12.000 \mathrm{~m}^{3}$, y1llık ise 4.38 milyon $\mathrm{m}^{3}$ olacaktır.

Kentsel Atık Su Arıtımı Yönetmeliği 11. maddesi a bendinde; "Mahallin en büyük mülki amiri, 10.000 eşdeğer nüfustan fazla toplama alanlarından hassas alanlara yapılacak tüm deşarjların Tablo 2'de belirtilen şartlara uyması için gereken tedbirleri alır" ve e bendinde "Mahallin en büyük mülki amiri, d bendi gereğince yeni belirlenecek hassas su alanlarında, bu alanların tespiti ve belirlenmesinden itibaren şartlara uyulması için gerekli tedbirleri alır" hükmü yer almaktadır. Buna göre atık su arıtma tesisinin Yönetmelik Tablo 2'de yer alan kirletici parametrelerine ait sınır değerlerini sağalacak ileri arıtma sistemini 2025 yılına kadar kurması gerekmektedir.

Atık su arıtma tesisine evsel atık sular toplanarak tek bir noktadan gelmektedir. Şehrin imar planı sınırları içerisinde tamamında kanalizasyon hizmeti bulunmaktadır. İmar planı dışında ticari alanlar, bağ bahçe evleri gibi alanlarda fosseptik kullanılmakta olup, belediyeye ait vidanjörle çekilen atık suların kabulü tesis tarafindan yapılmaktadır. Atık su arıtma tesisinin hidrolik tasarımı, en kötü durum senaryosu, yani maksimum 2025 debisi için gerçekleştirilmiştir. Hesaplamalar ayrıca 2025 minimum debisi ve 2040 maksimum debisine göre kontrol edilmiştir. Arıtılan suyun deşarj seviyesi, alıcı ortamın taşma seviyesi olarak alınmıştır. Arıtma tesisi sahası sel koşullarından korunmuştur. Bu nedenle Paşa Deresi'ne dere ıslah çalışmaları tasarlanmış ve uygulanmıştır. Çap $800 \mathrm{~mm}$ olan mevcut ana kollektör, planlanan atıksu arıtma tesisinin giriş pompa istasyonundan yaklaşık $50 \mathrm{~m}$ uzakta olacak şekilde yapılmıştır. Mevcut ana kollektör hattı arıtma tesisinin giriş pompa istasyonuna kadar uzatılmıştır. Atık su arıtma tesisi, ayrı aerobik çürütücüler kullanılarak çamur stabilizasyonu ile aktif çamur prosesine dayalıdır. Fiziksel arıtma, klasik aktif çamur, UV dezenfeksiyon bulunmaktadır. Atık su arıtma tesisinde 2019 yılında $3.413 .245 \mathrm{~m}^{3}, 2020$ yılında $3.570 .000 \mathrm{~m}^{3}$ atık su arıtılarak deşarj edilmiştir.

Atık suların arıtma düzeyinin iyileştirlmesi amacıyla belediyenin ileri arıtma sistemini kurması gerekmektedir. Bunun gerçekleşmesi için finansman ihtiyacına ve artan maliyetlerin karşılanması amacıyla atık su birim fiyatı artacağından su fiyatlarının sosyal açıdan değerlendirilmesi için ödeyebilirliğinin tespiti gerekmektedir.

\section{E. Yağmursuyu Sisteminin İncelenmesi}

Kanalizasyon şebekesi inşaatının tamamlanmasının ardından eski kanalizasyon sistemi yağmur suyuna terk edilmiştir. Ancak yeni yapılan kanalizasyon sisteminin eski kanalizasyon sistemine göre kot olarak daha yukarıda kalması nedeniyle yol kotu altındaki bina kanalizasyon giderlerinin kurtarılamaması nedeniyle eski kanalizasyon hattında devam eden abone bağlantıları bulunmaktadır. Şiddetli yağışların olduğu dönemlerde eski kanalizasyon hatlarından atık suların bina bodrumlarını doldurduğu tespit edilmiştir.

Şehrin genişlemesine paralel olarak yağmursuyu birikme alanları olan ve deşarj imkanı olmayan Bahçelievler, Harmanlar, Buğdaylı Mahallelerinde biriken suların deşarjının sağlanması için 2015 yılında İller Bankasına belediye tarafindan Yağmursuyu Toplama Projesi talebinde bulunulmuştur. İller Bankası Anonim Şirketi tarafindan, Yağmursuyu Kesin Projesi 28.12.2016 tarihinde onaylanmış olup, Yağmursuyu İnşaat İhalesi 27.12.2018 tarihinde yapılmıştır ve 21.02.2019 tarihinde yer teslimi yapılıp inşaatına başlanmıştır.

Onaylı projede yağmursuyu hattı uzunluğu $14 \mathrm{~km} 341 \mathrm{~m}$ olup, 6 adet yağmursuyu deşarj noktası bulunmaktadır. Projede iptal edilen yerler, ilave hatlar ve iş artırımları sonucu toplam proje $16.358,65 \mathrm{~m}$ yağmursuyu hattı ve 3.324,38 m 1zgara bağlantısı olarak yapılmıştır. Bu projenin toplam tutarı 14.462.413,02 TL (vergiler dâhil)'dir.

Yağmursuyu toplama projesi ile birlikte deşarj noktası olmayan alanlarda biriken yağmur sularının derelere ulaşması sağlanmıştır. Ancak binaların çatı oluklarının topladığı yağmur suları kanalizasyon sistemine bağlı olduğundan kanalizasyon hattının yağmur suyunu taşıyabilecek durumda olmamasından dolayı bodrum katlarda su baskınlarına neden olmaktadır. Bu yağmursuyu çatı oluk bağlantılarının iptal edilerek yağmur suyu sistemine yönlendirilmesi veya bu suların daha sonra bahçe sulaması gibi kullanımlarda değerlendirilmek üzere bir depoda biriktirilmesi önem arz etmektedir.

\section{F. İlçenin Alternatif Su Kaynaklarının İncelenmesi}

Belediyenin DSİ ile yaptığı görüşmeler sonucunda kente yaklaşık 6 km. uzaklıkta bulunan Bahçecik Köyü sınırları içerisinde su kuyusu açılmış ve 20 1/s su bulunmuştur. Bu suyun dağıtım sistemine bağlantısı için dağıtım ağı değişimi kapsamında İlbank’a talepte bulunulmuştur. Bahçecik köyü ile kuyu açılabilmesi için 2014 yılında 
başlayan süreç 2016 yılında kuyunun yerinin kararlaştırılmasıyla son bulmuştur. Bahçecik köyüne köy içme su sıkıntısı çektiği durumlarda içme suyu sorununun çözüleceği protokolde belirtilerek anlaşılmıştır.

İlbank teknik personelinin kente su sağlayan yer altı su kaynaklarının yetersiz olduğunu belirtmesi içme suyu şebekesi proje ihale ilanına çıkılabilmesi için su kaynağı bulunması gerektiğinin bildirilmesi üzerine 2018 yılında DSİ'nin gösterdiği yeni bir alan olan 7 km uzaklıktaki Karatepe köyü sınırları içerisinde kuyu açılması kararı alınmıştır. Köy muhtarlığı ile yapılan görüşmeler sonucu yine köyde su sıkıntısı olması durumunda su sorununun çözüleceği hükmü konarak protokol düzenlenmiştir.

DSİ tarafından Merzifon ve Havza ilçelerinin içme suyunu karşılamak için 2008 yılında ön inceleme raporu hazırlanarak Bakırçay Deresi üzerine baraj yapılarak ilçenin kuzeyinde bulunan Taşan Dağı tünelle geçilip, su temin projesine başlanmıştır. Ön inceleme etüdü 2010 yılında onaylanmış, 2011 'de Planlama İhalesi yapıllmıştır.

Derealan ve Bakırçay Derelerinin birleştiği alanın ilerisine yapılacak regülatörle su iletim tüneline aktarılacaktır. İletim tünelinin çapı $3 \mathrm{~m}$. ve uzunluğu ise $3700 \mathrm{~m}$. olarak planlanmıştır. İletim tünelinden Paşa Değirmen Deresine dökülen su, bu dere üzerine yapılması planlanan Merzifon Barajını besleyecektir. Baraj çıkışında arıtılan su, dağıtım depolarına aktarılacaktır. Baraj ile ilçeye ait su depoları arsındaki boru hatlarının yapımı da baraj projesine dahil edilmiştir. Projenin tamamlanmasıyla ilçenin 50 yıllık su sorununun çözülmesi planlanmıştır. Baraj göl alanında madencilik faaliyetine ilişkin ruhsatlı alanlar bulunduğundan belediye bu ruhsatların iptalini Maden İşleri Genel Müdürlüğünden istemiştir. 2012'de DSİ maden faaliyetleri ile çakıştığı ve işin devam edip etmeyeceği ile ilgili Genel Müdürlüğün karar vermesi gerektiği belirtilerek işi durdurmuştur. 2013 yılında projenin kaldığı yerden devamı ile ilgili DSİ karar almıştır. 2015 yılında MİGEM tarafından yapılan incelemede, projede yapılması planlanan regülatör tesisi ve su iletim hattının tünel başlangıcının taşınması halinde baraja su gelişinde artış olacağı ve sadece $4910 \mathrm{~m}$. uzunluğundaki su iletim hattının $5070 \mathrm{~m}$. uzunluğuna ulaşarak $160 \mathrm{~m}$. ilave yapılacağı belirtilmiştir. DSİ, proje içme suyu amaçlı olduğundan havzadaki madencilik faaliyetlerinin suyu kirleteceğini planlama raporunda bildirilmiştir.

Yeni Merzifon Barajı alternatifi dışında DSİ, Yakacık Gölet’i Rehabilitasyonu ve Gümüşhacıköy barajı alternatifini getirmiştir. Yakacık Gölet'inin su tutmadığı, jeomembran türü kaplamalarla sızdırmazlığının sağlanarak ve yükseltilerek içme suyu temininde faydalı olabileceği ancak bunun ilçenin su temini için yeterli olmayacağı belirtilmiştir.

Camiboğazı deresi üzerinde belirlenen, Gümüşhacıköy Barajı alternatifinde bu Gümüşhacıköy ilçesi ihtiyacı karşılandıktan sonra arta kalan suyun Merzifon'a verilmesi ve eksik kalan suyun ise Yakacık ve Paşa Göletlerinin rehabilite edilerek depolama hacimlerinin arttırılıp sağlanması öngörülmüştür. Camiboğazı Deresi mansabında Kuyma Deresi adını almaktadır. Kuyma deresi üzerinde ise 2000 ha alanı sulayan Duruçay Barajı bulunduğundan ve Kuyma Deresi üzerinde Su Kullanım Hakkı imzalamış olan Kuyma HES Projesi bulunduğu belirtilmiştir.

DSİ tarafından Çekerek çayı üzerinde Süreyya Bey Barajı’ndan içme suyu temini alternatifi düşünülmüş $150 \mathrm{~km}$ üzerindeki mesafede yüksek kot farkları, pompaj gereksinimleri dolayısıyla bunun mümkün olmayacağı belirtilmiştir. Yeni Merzifon Barajı dışındaki alternatiflerin Merzifon ilçesi için tek başına yeterli olmayacağ bildirilmiştir. Bu alternatifler dışında DSİ 7. Bölge Müdürlüğü sınırlarındaki Samsun Ladik Tersakan Barajı İçme ve Kullanma Suyu Temin Projesi geliştirilerek yörede bulunan bir kısım tarım arazilerine sulama suyu temini ile Amasya ili merkezi, Merzifon ilçe merkezi, Suluova ilçe merkezi, Havza ilçe merkezi ve proje sahasına yakın bölgedeki yerleşim birimlerinin içme suyu ihtiyaçlarının karşılanması amaçlanmıştır. Barajın planlama çalışmaları 2021 tarihi itibariyle başlamıştır.

Merzifon Gümüşhacıköy ovasının alt havzalarına bakıldığında, Merzifon-Gümüşhacıköy ovası jeolojik ve hidrojeolojik yapı, akifer tipi gibi özelliklerle beş bölüme ayrılmıştır: Merzifon ilçesi ile Çorum Devlet Karayolunun batısı boyunca uzanan tarım arazilerinin bulunduğu düzlük bölüm Merzifon Gümüşhacıköy Ovası, Merzifon ilçe merkezi ve çevresinde kalan bölüm Merzifon Konisi, Merzifon ilçe merkezi ile Çorum yolunun doğusunda kalan bölüm Ovanın Doğu Bölümü, ovanın Batı ve Kuzeyinde kalan alan Ovanın Kuzey ve Batı Bölümü, Güneyde bulunan Salhan Çayı vadisi ve çevresi ise Salhan Çayı Vadisi olarak isimlendirilmiştir. Merzifon Gümüşhacıköy ovasının alt havzası ova bölümü olarak adlandırılan kısmında rezervin tamamına yakınının tahsis edildiği görülmüştür. Merzifon ilçesine ait yeraltı su kuyularının bulunduğu Merzifon konisi bölümünde yeraltı suyu rezervinin üzerinde su tahsisi yapıldığı ve emniyetli yeraltı su rezervinin üzerinde çekim yapılmaktadır. Ovanın diğer alt havzalarında yeraltı suyu rezervinin yapılan tahsis miktarlarının üzerindedir. 
Ovanın Merzifon konisi dışındaki bölümlerinden Merzifon ilçesine su teminine ilişkin İçme Suyu Şebekesi Projesi kapsamında Karatepe köyünde açılan sondaj kuyusunun isale hattının olduğu görülmektedir.

İlçenin alternatif su kaynakalrı değerlendirildiğinde yeraltı suyuna olan bağımlılı̆̆ının azaltılması için DSİ tarafından planlanan içme suyu barajı projesinin bir an önce hayata geçirilmesi gerekmektedir. Aksi taktirde ilçe içme suyunda kısa zamanda sorunların çıkabileceği açıkça görülmektedir.

\section{G. İlçede Arıttlmış Atıksuların Yeniden Kullanım İmkânlarının İncelenmesi}

İlçe atık su arıtma tesisinde arıtılan sular deşarj noktası olan Paşa deresi üzerinden etrafta bulunan köyler tarafından talep edilmekte ve çekilmektedir. Su Yönetimi Genel Müdürlüğünün kullanılmış suların yeniden kullanım alternatiflerinin değerlendirilmesi projesi kapsamından 2020 yılında Amasya ili değerlendirme raporu oluşturulmuştur. Merzifon ilçesi için tesis çıkış sularının Organize Sanayi Bölgesinde değerlendirilmesi günlük ihtiyacın $300 \mathrm{~m}^{3}$ olması nedeniyle uygun bulunmamış ancak, ilerleyen yıllarda ihtiyacın artması halinde kullanılabileceği ifade edilmiştir. Sulama döneminde arıtılan $1.350 .000 \mathrm{~m}^{3}$ suyun 99 ha alanın sulama ihtiyacını karşılayacağı belirtilmiştir. Sulama suyu ihtiyacının tespitinde başlıca yetiştirilecek ürünler olarak şeker pancarı, patates, sebze, hayvan yemi, mısır olarak belirlenmiştir.

Çıkış suları tarımsal sulamada kullanılması halinde Sulama Sularının Kalitesi ve Kullanılmış Suların Yeniden Kullanılması Hakkında Yönetmelik Taslağı Ek-1 Tablo 1 ve Ek-1 Tablo 2'ye tabi olacaktır. Çıkış sularının sadece elektriksel iletkenlik parametresi açısından az ve orta kullanım kısıtında çıktığı, bu suların temiz su kaynaklarından sağlanacak su ile paçallanarak bu değerin "kullanım kısıtı yok" kriterine uygun hale getirilebileceği belirtilmiştir. Sulama alanlarında damla ve yağmurlama sulama sistemlerinin kullanılması halinde sulama sisteminde tıkanma olmaması için çıkış suyunun AKM (askıda katı madde) konsantrasyonunun düşük tutulması amacıyla dezenfeksiyon öncesinde kum filtresi kullanılması önerilmiştir.

Peyzaj sulama alternatifi ilçede bulunan park, bahçe ve yeşil alanların sulanması şeklinde düşünülmüştür. Yeşil alanlar dağınık halde geniş bir alanda olduğundan tankerlerle taşınarak sulama önerilmiştir. Peyzaj sulamada Escherichia koli konsantrasyonu, Sulama Sularının Kalitesi ve Kullanılmış Suların Yeniden Kullanılması Hakkında Yönetmelik Ek-1 Tablo 3 ve Ek-2 Tablo 5'e göre değerlendirilmiştir. Buna göre peyzaj sulamada Escherichia koli konsantrasyonu için herhangi bir kısıt bulunmamıştır. Halk sağlığı göz önünde bulundurularak ve arıtılan kullanılmış suların tesiste bulunan UV dezenfeksiyondan geçirildikten sonra peyzaj sulamada kullanılması önerilmiştir.

Arıtılmış suların yeniden kullanımı ilçedeki içme suyu haricindeki su taleplerinde kullanılmaması için önem arz etmektedir. Bu sayede suyun kullanımında yeraltı su kaynaklarına olan baskı hafifleyecektir. Arıtılan suyun yeniden kullanımına ilişkin politikalar geliştirilmelidir.

\section{H. İlçenin Kentsel Su Yönetimindeki Sorunların Değerlendirilmesi}

İlçede içme suyu temininde yeraltı su kaynakları önemli bir yer tutmaktadır. Temin edilen içme suyunun yaklaşık olarak \% 90’ı yeraltı suyundan sağlanmaktadır. İlçede bulunan tarım alanlarının bir kısmının yeraltı suyuna bağlı olması Paşa deresi ve Kuruçay deresindeki yeraltı su kaynaklarının hızlı bir şekilde sömürülmesine neden olmaktadır. Bu yüzden son yıllarda yaklaşık olarak yıllık $10 \mathrm{~m}$ düşüm meydana gelmekte bu durum su temininde önemli bir baskıya neden olmaktadır. Su seviyelerinin düşmesiyle birlikte kuyulardan elde edilen debilerde de düşümler olmaktadır. Suyun çıkarılması maliyetleri de her geçen gün artmaktadır. İlçede ruhsatlı kuyuların dışında açılan kaçak kuyuların tespitinin acilen yapılarak bölgede bulunan tüm kuyulardan çekilen suların miktarının tespit edilmesi için sayaç takılarak yeraltı suyu yıllık bütçesinin çıkarılması gerekmektedir. Yeraltı suyu tahsislerinin rezervi koruyacak şekilde planlanarak yapılması zorunluluk halini aldığ ${ }_{1}$ görülmektedir. Yıllık çekilen su miktarlarının tespiti ile birlikte hangi alanlarda ne tür önlemlerin alınması gerektiği açıkça ortaya çıkacaktır. Aksi takdirde yağışların azalmasının getirdiği etki ile birlikte yeraltı su kaynaklarının kısa sürede biterek içme suyu konusunda önemli sorunların çıkması muhtemel görünmektedir.

İlçe içme suyu şebekesinin eski olması ve mevcut talebe karşılık verememesi, şebeke ana hatlarının asbest çimentolu borulardan oluşması ortaya çıkan sık arızaların neden olduğu fiziki su kayıplarına sebep olması ve bu tip boruların insan sağlığına zararlı maddelerden oluşması nedeniyle acilen değişimi gerekmektedir. Her ne kadar belediyenin 2014 yılında başlayan İçme Suyu Şebekesi projesinin yapımı devam etse de bir an önce inşaat aşamasına geçilmelidir. Bu tür arızaların olduğu, su kayıplarının yoğun olduğu, içme suyu temininde kaynakları kıt olan bölgelerde bu tür projelerin hızlanması için sadece yerel yönetimlerin kıt mali kaynaklarla kendi haline kaldığı sistemin gözden geçirilmesi, altyapı varlıklarının ve performanslarının kayıtlarının yıllar itibarıyla 
tutularak had safhaya gelmeden çözümün kimsenin zarar görmeden üretilebileceği yapılanmaya gidilmesi gerekmektedir.

İlçenin içme suyu konusunda kıt kaynaklarının olduğu açık olmasına rağmen su temini için planlanan Yeni Merzifon Barajı ve Tersakan Barajı projelerinin çok yavaş ilerleme kaydetmesi sistemsel sorunların çözülmesi gerektiğini ortaya koymaktadır. Bu tür su kıtllğı bulunan ve nüfusun her geçen gün artmasıyla su talebinin arttığı bölgelerde su yönetimlerinin hızlı bir şekilde hareket etmesini sağlayan düzenlemelerin yapılması zorunludur.

Su kaynaklarının kıtlığı sorunu ilçede sadece içme suyu olarak düşünülmemeli, yeraltı suyundan tarımsal sulama yapılması, bağ alanlarının yoğun olması sulamada salma sulama yöntemlerinin kullanılmasıyla yeraltı sularından daha fazla çekim yapılması kaynakların hızlı şekilde sömürülmesine neden olmaktadır. Su yönetiminin tarımsal sulamadan elde edilecek tasarruflarla su kaynaklarının korunmasına katkı sağlayacağı şüphesizdir. Bu nedenle şehrin Paşa deresi ve Kuruçay deresi üzerine yapılan göletlerden en yüksek faydanın sağlanması için sulamada basınçlı sulama sistemlerine geçilmesi, böylece mevcut suyun daha fazla alanın sulanmasında kullanılacağı için derenin aşağı kısımlarındaki su kuyularından olan çekimlerin azalmasına veya düşümün düşük seviyelerde olmasına katkı sağlayacaktır.

İlçe içme suyu şebekesinde yapılacak düzenlemelerin yanı sıra yüzeysel sulama yöntemlerine veda edilmesiyle mevcut suyun verimli kullanılması sağlanmış olacaktır. Ancak bu zorlukların aşılmasındaki sorun çok sayıda kurumun, idarenin yetki ve sorumluluklarının olması, mali kısıtların bulunmasıdır. Örneğin belediyenin içme suyu şebekesini değiştirmesi için projenin hızlı şekilde yapılarak proje finansmanını gerçekleştirmesi ve yapıma geçmesi gerekirken, bölgedeki ilgili sulama kooperatiflerinin salma sulamadan vazgeçerek kapalı basınçlı sulama yöntemine geçmesi için finansman bulması gerekmektedir.

Belediyeye çevrede bulunan köylerin su şebekesi arızaları, kanalizasyon arızaları tamiratları ile ilgili talepler gelmektedir. Mevcut arıza ekipleri tarafından mümkün olduğunca bu arızaların da tamiratları yapılmaktadır. Bu köylerinde su hizmetleri noktasında ilgili kurumlarla birlikte kendi kendine yetmediği, zaten su tesislerinde birçok sorun bulunan belediyenin işgücünden pay alması su ve kanalizasyon hizmetlerinde teknik ve mali, idari anlamda bir yapılanma ihtiyacını ortaya çıkarmaktadır.

Arıtılan atık suların yeniden kullanım imkânı öncelikli olarak ek maliyete katlanmadan belediyenin yeşil alanları, park, bahçe alanları gibi peyzaj sulama alanlarında mümkün gözükmektedir. Tarımsal sulamada bu suların kullanımı için atıksu arıtma tesisinin işletme koşullarının iyileştirilmesi, paçallama, kum filtresi gibi revizyon ihtiyacı bulunmaktadır. Arıtılan suların yeniden kullanımında bazı sorunların olduğu dikkati çekmektedir. Anlık numuneler tam olarak gerçeği yansıtmayabilmektedir. Yeniden kullanımın toplumsal kabul edilebilirliği çok önemlidir. Bunun için toplumsal politikalar yürürlüğe konmalıdır. Yeniden kullanım yatırım gerektireceği, kontrolünün sürekli yapılması gerekeceği ve bu maliyetlerin nasıl karşılanacağına ilişsin belirsiz yanları bulunmakta ancak bu konuda politikaların oluştuurlarak bir an önce uygulamaya girmesi gerekmektedir.

Atık su arıtımı konusunda belediyenin 2025 yılına kadar ileri arıtma düzeyine geçme yükümlülüğü bulunmaktadır. Buna ilişkin teknik ve finansal çalışmaların yapılması gerekmektedir. Çünkü ilçede su kaynaklarının kıtlı̆̆ı, mevcut arıtma tesisi işletme masrafları, sermaye masrafları, içme suyu şebekesinin yenilenmesine ilişkin finansal zorluklar, yapımı tamamlanan yağmursuyu projesinin finansal masrafları (kredi ve faiz ödemeleri) gibi maliyetlerin sürekli artmasına neden olmaktadır. Bu artan maliyetlerle birlikte ilerleyen dönemde ödeyebilirlik (willingness-to-pay) sorunlarına yönelik çalışmaların yapılması da gerekecektir. Kentsel su ve kanalizasyon hizmetlerinin daha profesyonel yapılması ihtiyacı her geçen gün daha fazla ortaya çıkacaktır.

\section{SONUÇ VE ÖNERILER}

Merzifon ilçesinde içme suyu temini yeraltı suyundan ve kaynak sularından temin edilmektedir. Suyun yaklaşık \% 90'ının yeraltı suyundan temin edilmesi yeraltı su kaynaklarında baskı oluşturmaktadır. İçme syunun temin edildiği Paşa deresinde 2013-2020 yılları arasında debinin 100 m³/h'den 63 m³/h'e düştüğü, suyun çekildiği seviyenin 40,70 m'den 74,00 m seviyesine düştüğü görülmüştür. Aynı şekilde Kuruçay deresinde debinin 2014 yılında $85 \mathrm{~m}^{3} / \mathrm{h}$ 'den 2020 yılında $70 \mathrm{~m}^{3} / \mathrm{h}$ 'e düştüğü, yeraltı su seviyesinin 80,24 m'den $90 \mathrm{~m}$ seviyesine düştüğü tespit edilmiştir. Yeraltı su kaynaklarının yanı sıra kaynak sularının debilerinin de 2020 yılında 2017 yılına göre Muşruf kaynağında \% 81, Kayalık kaynağında \% 47 azaldığı görülmüştür. 
Merzifon ilçesinin su temin ettiği, Kuruçay ve Paşa derelerinin bulunduğu Merzifon konisinin beslenim miktarının 5 milyon $\mathrm{m}^{3} / \mathrm{y}^{1}$ iken içme suyu amaçlı yeraltı suyu çekim miktarının 6,5 milyon $\mathrm{m}^{3} / \mathrm{yll}$ 'dır. Bu durum su kaynaklarının hızla yok olduğunu göstermektedir.

Belediye içme suyu şebekesi 1979 yılında yapılmıştır. Eskiyen borular zamansız arızalar vermektedir. Arıza sayıları 2016'da 673 adet, 2017'de 734 adet, 2018'de 938 adet, 2019'da 768 adet, 2020'de ise 815 adet olmuştur. Arızalar sırasında su kayıpları yaşanmaktadır. Ayrıca içme suyu depolarının hacimleri yetersiz olup, sızıntı oluşmaktadır. Su depolarının iç yüzeylerinin fayans gibi kolay temizlenebilen malzemelerden yapılması gerekmektedir. Ayrıca ilçenin nüfusunun artmasıyla suya olan talebin ilerleyen yıllarda artacak olması gibi hususlar mevcut su şebekesinin acilen yenilenmesi ihtiyacını ortaya koymaktadır.

İçme suyu şebekesinde sistemin anlık basınç ve debi değişimlerinin izlenebildiği scada sisteminin kurulması gerekmektedir. Basınç düşümlerinin ve debideki artışların olduğu bölgelerin kayıp kaçak dinleme cihazları ile kontrol edilerek olası arızaların tespiti ve tamiratının hızlandırılması sağlanacaktır. Ayrıca bu alanların su denge tabloları oluşturularak kayıp kaçak su miktarları belirlenebilecek ve alınabilecek önlemlerin fayda maliyet analizleri yapılabilecektir.

İçme suyu şebekesine ait tüm boru çapı, boru koordinatları bina abone su tüketim ve borçları ile ilişkilendirilerek kayıt altına alınacağı bir sistemin kurulması tüm verilerin tek bir noktada erişilebileceği yazılımın kullanılması gerekmektedir. Elde edilen tüm veriler farklı kayıt ortamlarında bulunmaktadır. Ancak bu verilerin birbirleriyle ilişkisi bulunmaktadır. Bir binada hangi tür aboneliklerin olduğu, su tüketim miktarı, abonelik borç miktarları, abonelik bilgileri, tesisat bilgileri, su ve atık su alt yapılarına ilişkin bilgiler ve bu tür verilerin tüm şehir bazında raporunun oluşturulabileceği verilerin tek bir sistemden izlenmesi, veri girişlerinin aksatılmadan düzenli olarak yapılması gerekmektedir.

Su çekiminde kullanılan enerji miktarı 2020 yılında 2017 yılına göre 0,59 kwh'dan 0,76 kwh'ya çıkmıştır. $\mathrm{Bu}$ yeraltı su seviyesinin düşmesi sonucu enerji maliyetinin artması, cazibeli kaynak sularının debilerinin düşmesi nedeniyle olmuştur. Su şebekesindeki kayıp kaçakların azaltılmasıyla çekilen su miktarı, yeraltı su seviyesi düşümü ve dolayısıyla harcanan enerji miktarı da azalacaktır.

İlçede yeraltı su tahsislerinin rezerv miktarına göre belirlenmesi gerekmekte, kayıtsız kuyuların tespit edilerek ya acilen kapatılması ya da mevcut kuyularla birlikte sayaç takılarak yıllık çekim miktarlarının belirlenmesi ve buna yönelik önlemlerin alınması gerekmektedir. Mevcut su kaynağının korunması adına bu kaynaklardan yapılan tarımsal sulama için çekilen miktarların kontrol altına alınması, ilgili kooperatiflere ve şahıslara kapalı boru ile basınçlı sulama yapılması yönünde şartlar getirilmesi gerekmektedir.

İçme suyu tarifeleri belediye meclisi kararıyla belirlenmektedir. Suyun 2010 yılında $1,70 \mathrm{TL} / \mathrm{m}^{3} \mathrm{olan}$ fiyatının 2021 yılı güncel değerinin ise $6,01 \mathrm{TL} / \mathrm{m}^{3}$ tespit edilmişken, uygulamadaki 2021 fiyatı $3,75 \mathrm{TL} / \mathrm{m}^{3}$ 'tür. Su tarifelerinin belirlenmesine yönelik kriterlerin suyun işletme, bakım, sermaye, çevresel ve kaynak maliyetlerini içerecek şekilde belirlenerek uygulanması gerekmektedir. Aksi takdirde suya değerinde fiyatlandırma yapılmaması nedeniyle verimli kullanılmamasına neden olunacaktır. Suyun fiyatının belirlenmesinde tüm maliyet unsurlarının hesaba katılması ardından ödeyebilirlik analizleri yapılarak fiyatlandırma politikası belirlenmelidir.

Şebekeye verilen su miktarı 2020 yılı için $6.550 .634 \mathrm{~m}^{3}$ iken tahakkuk eden su miktarı $3.190 .606 \mathrm{~m}^{3}$ gelir getirmeyen su miktarı ise $3.360 .028 \mathrm{~m}^{3}$ 'tür. Gelir getirmeyen su miktarının azaltılması için kayıp kaçak su miktarının düşürülmesi gerekmektedir. Bunun için su şebekesinden, su sayaçlarının hassasiyertinden ve kaçak su bağlantılarından kaynaklanan kayıp kaçakların ortadan kaldırlmasına yönelik uzun vadeli planlamaların yapılmalıdır.

İçme suyu şebekesinde fiziki kayıpların yanı sıra idari kayıpların da denetlenmesi önem arz etmektedir. Yasa dışı su bağlantılarının sürekli olarak denetlenmesi, sayaçlardaki ölçüm hatalarının en az düzeye indirilmesi için eskiyen, arızalı sayaçların anında değiştirilerek suyun ölçümünün yapılması, şehrin kenar bölgelerinde yer alan bağ bahçe evleri, hobi bahçesi gibi mekân dışı su kullanımı potansiyeli yüksek olan bölgelerde su bağlantı denetlemelerinin yanı sıra düzenli olarak aylık su bütçelerinin çıkarılması yoluyla takip edilmesi, içme suyu ile bu alanlardaki meyve ve sebze sulanmasının durdurulması su talebinin ve idari kayıpların kontrol altına alınmasında etkili olacaktır. Aylık olarak su sarfiyatı yüksek abonelerin sayaçları düzenli olarak kontrol edilmelidir.

Su abone sayaçlarının \% 35, 5'ini ön ödemeli elektronik sayaçlar oluşturmaktadır. Bu sayaçların işletme maliyeti ve ilk kurulum maliyetleri yüksektir. Ayrıca işletme aşamasında çok fazla vana arızası vererek eksiye 
düşen tipleri bulunmaktadır. Bu durum işleyişi aksatmaktadır. Otomatik ödeme araçlarına ve sayaç hassasiyetine öncelik veren sayaç değişim politikalarının uygulanması gerekmektedir.

Abonelere uygulanan su tarifelerinde bir çok abone tipi bulunmaktadır. Abone tiplerinin mesken, ticari, resmi gruplarda oluştuurlarak sadeleştirilmesi değerlendirmelerde basitlik sağlayacaktır. Su tarifelerinde kademelendirme $50 \mathrm{~m}^{3}$ su kullanımdan sonra gerçekleşmektedir. Bunun daha düşük su miktarlarına çekilerek su kullanımında verim artırılacaktır.

$\mathrm{Su}$ ve kanalizasyon hizmetlerinin yürütülmesinde teknik personel ve kalifiye usta ihtiyacı önem arz etmektedir. Su bağlantılarının montajının yapılmasında, arızaların tamiratlarının kaliteli bir şekilde yapılmasında kalifiye personele gereksinim duyulmaktadır. Su ve atık su hizmetleri mesai saati gözetilmeden iş gücü gerektirerek yapılan bir hizmet türüdür. Bu hizmetleri gerçekleştirecek personelin işe başladıktan sonra daha az iş yükünün olduğu birimlerde çalışmak istemesi diğer personelinde performansını etkileyeceğinden bu hususa dikkat edilmelidir. Bir çok iş kolunun olduğu belediyelerde su ve kanalizasyon hizmetlerinde çalışacak personelin kalifiye olması gerekmektedir. Bu sektörde çalışabilecek kişiler için eğitim, sertifika verilmesini sağlayacak düzenlemelerin yapılması, standartların oluşturlmsı, yeterliliği olmayan kişilerin su tesisat yapımı, tamiri işlerinin yapmasinın engellenmesi gerekmektedir.

Su tasarrufu konusunda halkın bilinçlendirilmesi faaliyetlerine önem verilmelidir. İlçede bina etrafındaki bahçe kısımlarında insanların su talebinin yoğun olduğu ve kıt olduğu yaz aylarında domates, salatalık, biber gibi su tüketimi yüksek olan sebzeleri hortumla sulama yaptığı, yeşil alan sulamalarının su temininin çok zor bir bölge olmasına rağmen devam ettiği görülmektedir. Yeraltından temin edilen içme suyu ile bu tür sulama faaliyetlerinin gerçekleştirilmesi yerine, binaların çatı oluklarında yağışlarda biriken suların bir depo ile depolanarak kullanılması, yeşil alan sulamasında atık su arıtımı sonucu oluşan suyun ilgili standartları sağladıktan sonra kullanımı önem arz etmektedir. Şebekeden alınan su ile bu tür sulamaların yapılması kesinlikle yasaklanmalıdır.

Kanalizasyon sisteminin kullanımı konusunda da halkın bilinçlendirilmesi gerekmektedir. Kanalizasyon şebekesinde yıllık bin üzerinde arıza giderilmektedir. Bu arızaların en önemli nedeni ıslak mendil kullanımı ve bunun kanalizasyon sistemine atılmasıdır. Arızalarda ıslak mendillerin birikerek kanalizasyon abone bağlantılarını ve ana hatlarını tıkadığı görülmektedir. Özellikle yağışlı zamanlarda çatı oluklarındaki yağmur suyunun kanalizasyon sistemine girerek bu tür kanalizasyon sistemine atılan atıkların boru giderlerini tıkaması sonucu su baskınlarına neden olduğu görülmektedir.

Kanalizasyon şebekesinin arıza sayılarının $2015^{\prime}$ de 1152,2016 'da 1392 , 2017'de 1011, 2018 'de 741, 2019'1349, 2020'de 1234 adet olarak gerçekleşmesi kanalizasyon şebekesinin düzenli olarak combine kanal açma aracıyla temizlenmesini zorunlu kılmaktadır. Ayrıca kanalizasyon şebekesine ıslak mendil, yağ, katı maddeler atılmasının önlenmesi için halkla ilişkiler çalışmalarına ağırlık verilmelidir.

Arıtılan suyun yeniden kullanımı sağlanarak içme suyunun tarımsal, peyzaj gibi alanlarda kullanımdan tasarruf sağlanmalıdır. Arıtılan suyun arıtma düzeyinin iyileştirilmesi, halkın bu suyun mekan dışı alanlarda kullanımının kabul etmesine yönelik halkla ilişkiler çalışmaları yapılmalıdır.

\section{KAYNAKLAR}

[1] Tanrıvermiş, H. \& Aliefendioğlu, Y. (2008). Türkiye'de Su Kaynaklarından Sulama Amaçlı Yararlanma Yöntemlerinin Değerlendirilmesi, Üçüncü Sektör Kooperatifçilik, 43(1), 88-111.

[2] Aküzüm, T., Çakmak, B. \& Gökalp, Z. (2010). Türkiye’de Su Kaynakları Yönetiminin Değerlendirilmesi. Tarım Bilimleri Araştırma Dergisi, 3(1), 67-74.

[3] Özçelik, A., Tanrıvermiş H., Gündoğmuş E. \& Turan A., (1999). Türkiye'de Sulama İşletmeciliğinin Geliştirilmesi Yönünden Şebekelerin Birlik ve Kooperatifleşme Devri ile Su Fiyatlandırma Yöntemlerinin İyileştirilmesi Olanakları", Tarımsal Ekonomi Araştırma Enstitüsü, 32.

[4] Lambert, A. O. (2001). International Report on Water Losses Management and Techniques. Report to IWA Berlin Congress, Water Science and Technology: Water Supply, 2(4), 1-20.

[5] Tietenberg, T. \& Lewis, L. (2012). Environmental and Natural Resource Economics. Pearson Education, USA.

[6] Türkiye İstatistik Kurumu (2021). Web Sitesi: https://data.tuik.gov.tr/Bulten/Index?p=AdreseDayal\%C4\%B1-N\%C3\%BCfus-Kay\%C4\%B1t-Sistemi-Sonu\%C3\%A7lar\%C4\%B1-2020-37210\&dil=1/ (Erişim Tarihi: 09.06.2021.)

[7] İller Bankası Genel Müdürlüğü. (1999). Merzifon (Amasya) İçme Suyu Projesi Hidroloji Raporu. Ankara. 
[8] Duran, O. (2010). Kamu Yönetimi Reformu Çerçevesinde Türk Su Yönetimi. Doktora Tezi. Ankara Üniversitesi, Sosyal Bilimler Enstitüsü Siyaset Bilimi ve Kamu Yönetimi, Yönetim Bilimleri Anabilim Dalı. Ankara.

[9] Karakoçak, B. (2008). An Integrated Approuch to Water Management in Kayseri: Water Collection and Storage Design for Kayseri Harikalar Diyarı Water Ski Park. Çevre Bilimleri Enstitüsü, İstanbul Teknik Üniversitesi, İstanbul.

[10] Sümer, V. (2011). The European Union Water Framework Directive and Turkey's Water Management Policy: An Analyses. Orta Doğu Teknik Üniversitesi Uluslararası İlişkiler Bölümü, Yüksek Lisans Tezi. Ankara.

[11] TC Çevre ve Şehircilik Bakanlığı. (2005). Merzifon Çevre Durum Raporu, Amasya.

[12] Merzifon Belediyesi. (2008). Türkiye’de Atık Su Arıtma Tesisleri Iç̧in Teknik Destek. Merzifon Belediyesi Su ve Atık Su Master Planı, Merzifon.

[13] Merzifon Belediyesi. (2012a). Merzifon İlave ve Revizyon Imar Planı Açıklama Raporu. Merzifon Belediyesi İmar ve Şehircilik Müdürlüğü, Merzifon.

[14] Devlet Su İşleri Genel Müdürlüğü 7. Bölge Müdürlüğü (2012a). Merzifon Etüt Raporu. Samsun.

[15] Devlet Su İşleri Genel Müdürlüğü (2015b). Amasya-Merzifon ve Samsun - Havza İlçeleri İçme ve Kullanma Suyu Projesi Planlama Raporu. Samsun.

[16] Merzifon Belediyesi. (2015a). Merzifon Belediyesi 2015-2019 Stratejik Plan1. Merzifon.

[17] Merzifon Belediyesi. (2021b). Merzifon Belediyesi Kent Bilgi Yönetim Sistemi.

[18] Merzifon Belediyesi. (2021c). Merzifon Belediyesi Scada (Merkezi Denetim ve Veri Toplama) Sistemi.

[19] Merzifon Belediyesi. (2020d). Faaliyet Raporları. Merzifon.

[20] İller Bankası AŞ. Genel Müdürlüğü Proje Dairesi Başkanlığı. (1975). Merzifon İçme suyu Projesi, Ankara.

[21] İller Bankası AŞ. Genel müdürlüğü Proje Dairesi Başkanlığı. (2016). Merzifon Yağmursuyu Kesin Projesi, Ankara.

[22] İller Bankası AŞ. Samsun Bölge Müdürlüğü. Merzifon İçme Suyu Projesi Etüt Raporu. Samsun.

[23] Muhammetoğlu, H. \& Muhammetoğlu A. (2017). İçme Suyu Temin ve Dağıtım Sistemlerindeki Su Kayıplarının Kontrolü El Kitabı. T.C. Orman ve Su İşleri Bakanlığı Su Yönetimi Genel Müdürlüğü. Ankara.

[24] Tuna M. (1995). Atık Su Arıtma Tesisleri Maliyet Indeksi ve Debi Maliyet İlişkileri. Doktora Tezi. İstanbul Teknik Üniversitesi Fen Bilimleri Enstitüsü, İstanbul.

[25] Katip, A. (2018). Arıtılmış Atıksuların Yeniden Kullanım Alanlarının Değerlendirilmesi. Ömer Halisdemir Üniversitesi Mühendislik Bilimleri Dergisi, 7(2), 541-557.

[26] Zarnikau, J. (1994). Spot Market Pricing of Water Resources and Efficient Means of Rationing Water Resources During Scarcity, Resource and Energy Economics 16(3), 189-210.

[27] Armut, S. (2019). Kentsel Su Yönetimi ve Suyun Fiyatlandırılması: Merzifon İLçesi Örneği, Mehmet Akif Ersoy Üniversitesi Sosyal Bilimler Enstitüsü Dergisi, 11 (29), 404-420.

[28] Tarım ve Orman Bakanlığı Su Yönetimi Genel Müdürlüğü (2020). Kullanılmış Suların Yeniden Kullanım Alternatiflerinin Değerlendirilmesi Projesi. Amasya İli Değerlendirme Raporu. Ankara. 